\title{
Triclosan in water, implications for human and environmental health
}

\author{
L. W. B. Olaniyan ${ }^{1,2^{*}}$, N. Mkwetshana ${ }^{2}$ and A. I. Okoh ${ }^{1,2}$
}

\begin{abstract}
Triclosan (TCS) is a broad spectrum antibacterial agent present as an active ingredient in some personal care products such as soaps, toothpastes and sterilizers. It is an endocrine disrupting compound and its increasing presence in water resources as well as in biosolid-amended soils used in farming, its potential for bioaccumulation in fatty tissues and toxicity in aquatic organisms are a cause for concern to human and environmental health. TCS has also been detected in blood, breast milk, urine and nails of humans. The significance of this is not precisely understood. Data on its bioaccumulation in humans are also lacking. Cell based studies however showed that TCS is a pro-oxidant and may be cytotoxic via a number of mechanisms. Uncoupling of oxidative phosphorylation appears to be prevailing as a toxicity mechanism though the compound's role in apoptosis has been cited. TCS is not known to be carcinogenic per se in vitro but has been reported to promote tumourigenesis in the presence of a carcinogen, in mice. Recent laboratory reports appear to support the view that TCS oestrogenicity as well as its anti-oestrogenicity play significant role in cancer progression. Results from epidemiological studies on the effect of TCS on human health have implicated the compound as responsible for certain allergies and reproductive defects. Its presence in chlorinated water also raises toxicity concern for humans as carcinogenic metabolites such as chlorophenols may be generated in the presence of the residual chlorine. In this paper, we carried out a detailed overview of TCS pollution and the implications for human and environmental health.
\end{abstract}

Keywords: Cytotoxicity, Endocrine disruptor, Micro-pollutant, Triclosan, Water

\section{Background}

Triclosan (TCS) is a broad-spectrum antimicrobial agent in some personal care products such as soap, sanitizer and skin cream (Kirk-Othmer 1993; MacIsaac et al. 2014; Perencevich et al. 2001; Schweizer 2001). Its widespread use in homes and in health care centres may have explained its versatility as a water micro-pollutant (Helbing et al. 2011; Kolpin et al. 2002; Li et al. 2010; Loraine and Pettigrove 2006; Park and Yeo 2012; Reiss et al. 2002). TCS has been mentioned (Foran et al. 2000) as an endocrine disruptor (ED), a group of compounds known to interfere with hormone functions (Wingspread Consensus Statement 1991).

Structurally, TCS molecule possesses functional groups for both phenol (5-chloro-2-(2,4-dichlorophenoxy)

\footnotetext{
*Correspondence: 201414591@ufh.ac.za

1 SAMRC Microbial Water Quality Monitoring Centre, University of Fort Hare, Private Bag X1314, Alice, Eastern Cape 5700, South Africa Full list of author information is available at the end of the article
}

phenol) and ether (2,4,4-trichloro-2-hydroxydiphenyl ether) (Fig. 1). Its lipophilicity ( $\log \mathrm{K}_{\mathrm{ow}}=4.8$ octanolwater partition coefficient) suggests bioaccumulation in fatty tissues which raises toxicity concern.

The hormonal activity of TCS (Crofton et al. 2007) is widely acknowledged in vitro (Huang et al. 2014) and in vivo, in laboratory (Stoker et al. 2010) and aquatic (Ishibashi et al. 2004) animals which raises fear for human health. Evidence of human toxicity is still a matter for debate in scientific circles, however some state authorities such as in Minnesota are considering a ban on all TCS-containing products (Dhillon et al. 2015) or a restriction (TIME 2014), partly due to the reported TCSresistant bacteria or ostensibly yielding to the pressure mounted by some professional bodies (APUA 2011b) for the perceived adverse effects on health. Apart from its widely reported adverse effects on cellular metabolism, its ecotoxicity also raises fear of dwindling economic fortunes from water resources. The present work attempts 


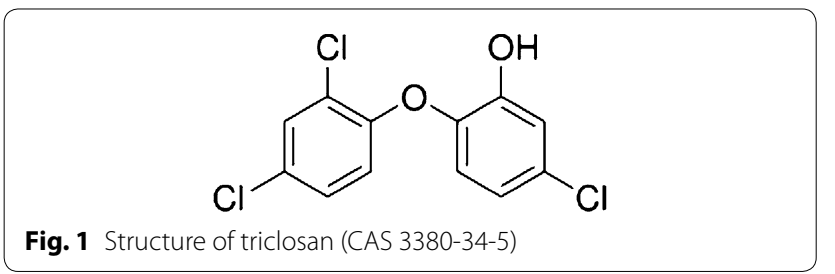

to review available data on environmental impact as well as evidence suggestive of human toxicity and to suggest future research directions.

\section{Triclosan exposure for humans}

TCS is approved for topical administration at maximum concentration of $0.3 \%(\mathrm{w} / \mathrm{w})$ in humans (European Commission 2010; Larsson et al. 2014; MacIsaac et al. 2014) and $0.03 \%(\mathrm{w} / \mathrm{w})$ in oral medications in some countries (Canada 2007). It is used as an additive in polymer matrices such as polyolefin and polyethylene which may contain $1 \%(\mathrm{w} / \mathrm{w})$ to $10 \%(\mathrm{w} / \mathrm{w})$ TCS in some plastics industries (NICNAS 2009). Current annual global TCS production is not known to us but as many as are using the over 200 TCS-containing products as well as workers where these products are manufactured risk TCS exposure. Previous reports estimated over ' 1500 tons' of TCS per year entering consumer markets globally (Singer et al. 2002) and estimated value of well over $1.1 \times 10^{5} \mathrm{~kg} /$ year of TCS have been released into wastewater in the United States (Heidler and Halden 2007). Direct application of TCS-based products such as soaps, deodorants and toothpastes is the primary source of human exposure to TCS (Allmyr et al. 2006; Fang et al. 2014; MacIsaac et al. 2014). Occupational and environmental exposures have also been documented in humans (Geens et al. 2009). Among workers, dermal as well as inhalation are the routes of exposure. TCS bioavailability via inhalation is thought to be $100 \%$ (NICNAS 2009) but toxicokinetic data from this exposure route are lacking.

Ability of certain seafood to accumulate TCS is a route of TCS exposure to humans (Adolfsson-Erici et al. 2002). Rüdel et al. (2013) recorded maximum TCS of $11.7 \mathrm{nmol} / \mathrm{kg}$ in fish. Certain plants can also accumulate TCS in their tissues (Pannu et al. 2012) including plant foods such as lettuce (Prosser and Sibley 2015) which may occur following their cultivation in soils amended with biosolids, manure or irrigated with wastewater. For example Pannu et al. (2012) reported triclosan in radish at $31.8 \mu \mathrm{mol} / \mathrm{kg}$ dry weight $(\mathrm{dw})$ when the plants were grown in soil with TCS concentration of $34.2 \mu \mathrm{mol} / \mathrm{kg}$ dw. However such accumulation becomes something of toxicological concern to humans (hazard quotients $\geq 0.1$ ) (Health Canada and Environment Canada 2012; US FDA 2010) if the accumulation has been stored in the edible portions of the plant (Aryal and Reinhold 2011; Wu et al. 2012a) though it has been recorded that TCS translocation from the plant roots can reach the above-ground parts (Wu et al. 2010).

In infants exclusively on breastfeeding, breast milk presents major route of exposure to TCS (Table 1). In highly industrialized countries such as USA, TCS concentration in breast milk as high as $2.1 \mathrm{~mol} / \mathrm{kg}$ lipid has been reported (Dayan 2007) which should be of health concern to the young because of their immature drug metabolizing pathways making them vulnerable to the impact of TCS. On average, TCS concentration in drinking water is below parts per billion (Table 2) showing that it may not be a quantitative source of TCS exposure to humans.

The estimated acceptable daily intake for TCS is $0.17 \mathrm{nmol} / \mathrm{kg} /$ day (Blanset et al. 2007) and some drinking water levels of TCS have been found to be higher than this estimate (Table 2).

TCS after disposal, drains ultimately into underground (Sorensen et al. 2015) and to surface waters (Table 3) where it may finally reach humans by drinking contaminated water or via the food chain such as consumption of animals and vegetation exposed to TCS (Park and Yeo 2012). An annual discharge of 18 tonnes of TCS to the surface water in USA had been reported, with more than half this volume coming from wastewater treatment plants (WWTPs) (Halden and Paul 2005). Underground water from shallow wells and boreholes has been reported to contain up to $0.10 \mathrm{nM}$ TCS (Sorensen et al. 2015). Concentrations of TCS in some untreated surface waters were reported to range from 7.9 to $39 \mathrm{nM}$ (Kolpin et al. 2002; Perez et al. 2013). High value of $297.7 \mathrm{nM}$ was reported in the influents of certain wastewater treatment plants (Kumar et al. 2010) while effluents concentrations ranging from 0.41 to $3.5 \mathrm{nM}$ were reported in treated wastewater effluents (Glassmeyer et al. 2005; Snyder et al. 2008).

\section{Triclosan absorption in humans}

TCS absorption in humans and animals can be through dermal (Fang et al. 2014; Moss et al. 2000; Queckenberg et al. 2010), mucous membranes of the oral cavity

Table 1 Infant exposure to triclosan via breast milk (NICNAS 2009)

\begin{tabular}{llll}
\hline Age (month) & $\begin{array}{l}\text { Average milk } \\
\text { intake (g/day) }\end{array}$ & $\begin{array}{l}\text { Body weight } \\
\text { (kg) }\end{array}$ & $\begin{array}{l}\text { Internal triclosan } \\
\text { dose (nmol/kg } \\
\text { body wt/day) }\end{array}$ \\
\hline 1 & 751 & 4.7 & 10 \\
2 & 725 & 5.6 & 8.5 \\
3 & 723 & 6.2 & 7.6 \\
4 & 740 & 6.7 & 7.3 \\
\hline
\end{tabular}


Table 2 Triclosan concentrations in drinking water

\begin{tabular}{llll}
\hline Source & Concentration $(\mathbf{n M})$ & Frequency-of detection (\%) & References \\
\hline Tap water & 0.17 & 34 & Yang et al. (2014) \\
Tap water & 0.048 & 75 & Padhye et al. (2014) \\
Tap water & 0.21 & 63 & Li et al. (2010), Perez et al. (2013) \\
Fountain water & $0.021-0.052$ & & Yang et al. (2014) \\
& 0.36 & 45 & 75 \\
\hline
\end{tabular}

Table 3 Triclosan concentrations in aquatic systems

\begin{tabular}{lll}
\hline Source & Concentration (nM) & References \\
\hline Surface water & & Ying et al. (2007) \\
Natural streams/rivers & nd-7.9 & Halden and Paul (2005) \\
& 0.26 & Fair et al. (2009) \\
Streams with input of raw wastewater & 5.5 & Kantiani et al. (2008) \\
Ebro basin (Spain) & nd-0.98 & Shen et al. (2012) \\
Danshuei River (Taiwan) & $0.015-0.036$ & Pintado-Herrera et al. (2014) \\
River (SouthWest Spain) & $0.25 \pm 0.0017$ & Pintado-Herrera et al. (2014) \\
Sea (SouthWest Spain) & $0.23 \pm 0.0034$ & Pintado-Herrera et al. (2014) \\
Undergroundwater (boreholes/wells) & & Sorensen et al. (2015) \\
South West Spain & $0.23 \pm 0.0035$ & Karnjanapiboonwong et al. (2011) \\
Kabwe, Zambia & $6.9 \times 10^{-5}-1.0 \times 10^{-4}$ & Chi et al. (2013) \\
West Texas USA & nd-0.18 & Anumol and Snyder (2015) \\
Wastewater-treatment plants & & Anumol and Snyder (2015) \\
Treated wastewater (Midlands, UK) & Mean $0.25-1.51$ & Pintado-Herrera et al. (2014) \\
Influent (USA) & $6.91-10.36$ & $0.044-0.097$ \\
Final effluents (USA) & $0.33 \pm 0.028$ & \\
Effluent (South West Spain) & &
\end{tabular}

nd not detected

(Lin 2000) or gastrointestinal tract (Bagley and Lin 2000) routes and reaches systemic circulation (Hovander et al. 2002). It penetrates the skin less rapidly and less extensively in humans than in rats (Chedgzoy et al. 2002; Moss et al. 2000), a factor to consider in risk assessment. Animal experiments had shown that tissue levels of TCS are less when administered through dermal route than via oral route. Percutaneous absorption is interfered with by the vehicle of administration. Propylene glycol increases percutaneous absorption of TCS in mice however no such change is observed when $95 \%$ ethanol is used (Fang et al. 2014).

TCS absorption and distribution are rapid in humans. Dermal absorption is generally 3-7 \% (Moss et al. 2000; NICNAS 2009; Queckenberg et al. 2010), $6.3 \%$ was reported in vitro using human skin (Moss et al. 2000). Lin (2000) reported that 7.33 \% TCS was retained from mouthwash containing $0.03 \%$ TCS but when swallowed the absorption was higher at the gastrointestinal tract (Bagley and Lin 2000) which has been reported to be near-completion (NICNAS 2009). Maximum blood level was reported to have been reached when exposed orally within $3 \mathrm{~h}$ while significant amount of the dose was excreted $24 \mathrm{~h}$ post-dose (Sandborgh-Englund et al. 2006). Studies carried out on human subjects using TCScontaining cosmetics showed variable but significant amounts of TCS in their body fluids (Table 4) when compared with the unexposed controls (Allmyr et al. 2006; Sandborgh-Englund et al. 2006). A single oral dose of $13 \mu \mathrm{mol}$ TCS to human subjects increased plasma TCS level to $0.84 \mu \mathrm{M} 4 \mathrm{~h}$ after ingestion and when repeated thrice daily for 12 days increased the plasma level to 1.2 $\mu \mathrm{M}$ (Bagley and Lin 2000) but administration of $14 \mu \mathrm{mol}$ TCS per oral increased the plasma level to $0.75 \mu \mathrm{M}, 3 \mathrm{~h}$ post-dose (Sandborgh-Englund et al. 2006). The results are not comparable because of certain militating factors which included sample size and inter-subject variation. Before entry into the blood stream, TCS is 
Table 4 Triclosan concentrations in human fluids

\begin{tabular}{llll}
\hline Fluid & Concentration (nM) & Location & References \\
\hline Serum & $4.1-41.4$ & Spain & Azzouz et al. (2016) \\
Plasma & $0.035-1200$ & Australia, Sweden & Allmyr et al. (2006, 2008) \\
Urine & $8.3-13,090$ & USA & Calafat et al. (2008), Allmyr et al. (2008) \\
& $0.56 \pm 1.8^{\mathrm{a}}$ & India & Xue et al. (2015) \\
& $0.16 \pm 0.27^{\mathrm{b}}$ & India & Xue et al. (2015) \\
& 1630 & USA & US CDC (2014) \\
& $1.1-7.3$ & Spain & Azzouz et al. (2016) \\
& $0.51 \pm 0.53$ & USA & Maclsaac et al. (2014) \\
Breast milk & $0.86-7.3$ & Spain & Azzouz et al.(2016) \\
& $0.062-252$ & USA, Australia, Sweden & Allmyr et al. (2008), Adolfsson-Erici et al. (2002) \\
\hline
\end{tabular}

a Non-obese

b Obese

conjugated by the skin (Moss et al. 2000). Both percutaneous and gastrointestinal tract absorptions are susceptible to first-pass metabolism wherein TCS is conjugated with glucuronates and sulphates (Moss et al. 2000), the process known to be the cellular means of detoxication. Toxicokinetic data on TCS oral and dermal administrations in humans appear limited. In a controlled exposure study, some $70 \%$ of the total plasma TCS are in conjugated form (Sandborgh-Englund et al. 2006) and would be voided predominantly via urine, the balance is in unconjugated form expected to evoke physiological responses. However, from data presented by Allmyr et al. (2009), the $30 \%$ balance equal to $0.03-0.08 \mu \mathrm{M}$ TCS in the plasma failed to activate pregnane $\mathrm{X}$ receptor (hPXR) regardless of the high level of exposure.

In addition to blood, detectable levels of TCS have been recorded in breast milk (Dayan 2007) and urine (Benny et al. 2014; Table 4). Azzouz and colleagues (2016) reported 41.4, 7.3 and 7.3 $\mathrm{nM}$ in whole blood, breast milk and urine respectively as maximum TCS concentrations from healthy humans. In highly industrialized nations such as U S, about two-thirds of 90 girls, aged 6-8 years old have been reported to exhibit detectable urinary TCS ranging from $5.5 \mathrm{nM}$ to $3.3 \mu \mathrm{M}$ (Wolff et al. 2007). Among some Chinese school children aged 3-24 years old, higher TCS levels in urine (geometric mean of $13 \mathrm{nM}$ ) were reported among females than their male counterparts, significantly (93\% detection frequency) among those between 18 and 24 years (Li et al. 2013). It is presently not clear if gender plays a definitive role in TCS metabolism as reports by Clayton et al. (2011) from National Health and Nutrition Examination Survey (NHANES) among US population aged 50 years had shown that males had higher urinary TCS than females (472.34 vs. $329.42 \mathrm{nM}$ ) whereas data of Yin et al. (2015) from respondents $(<50$ years) containing equal number of both sexes reported higher geometric mean for urinary TCS among females than males $(1.83 \mathrm{nmol} / \mathrm{g}$ creatinine vs. $1.1 \mathrm{nmol} / \mathrm{g}$ creatinine). The data from US CDC (2014) however appeared not in support of this observation.

\section{Metabolism of triclosan}

TCS is readily metabolized and may be extensively distributed in tissues including the brain (Geens et al. 2012) showing its ability to cross blood-brain barrier. It induces cytochrome P450 in rat hepatic microsomes, the enzymes responsible for its metabolism (Hanioka et al. 1997; Kanetoshi et al. 1992). It undergoes glucuronidation and sulphation in animals and humans (Sandborgh-Englund et al. 2006; Wang et al. 2004) regardless of the route of administration. In mice, TCS is metabolizable into sulphate, glucuronide, 2,4-dichlorophenol, and hydroxyl derivatives. Small amount (0.36 \%) of unconjugated TCS has been detected in the blood plasma when administered intraperitoneally (Cherednichenko et al. 2012). In rats as well as in humans, topical application of TCS on the skin generates a fraction of the sulphate conjugation product of the compound leaving higher amount unconjugated (Moss et al. 2000). In rats and mice, free TCS is excreted in the bile and voided via faeces (Fang et al. 2014).

TCS may inhibit the activities of the conjugating enzymes, glucuronyltransferases and sulphotransferases, towards 3-hydroxybenzo( $\alpha$ )pyrene, acetaminophen and bisphenol A in human liver microsomes (Wang et al. 2004) possibly blocking the elimination of these compounds and at the same time increasing their toxicities when co-administered. Glucuronate conjugation predominates in humans and is secreted in urine along with the unconjugated specie (Arbuckle et al. 2015; Benny et al. 2014; Weiss et al. 2015). Elimination half-life for TCS is higher in humans than in the laboratory animals 
such as rats (for example, 13-29 h in humans, $25-32 \mathrm{~h}$ in hamsters, $10-15 \mathrm{~h}$ in rats and $8-12 \mathrm{~h}$ in mice) when orally administered (NICNAS 2009). Elimination halflife is related to drug toxicity. Based on this, it is expected that TCS should be more toxic when applied under similar conditions to rats than humans and this needs be taken into consideration in human risk assessment using animal data.

\section{Endocrine disruption activity and toxicity of triclosan}

Mechanism of endocrine disruption by exogenous agents can take many forms (Colborn et al. 1993; Golden et al. 1999; Hollander 1997; Solomon and Schettler 2000; Wingspread 1991), the commonly encountered is the inhibition of the hormone (agonist) from binding its receptors by competing for the receptor binding sites with the antagonist. This is one mechanism through which TCS exhibits its endocrine disruption activity (Ahn et al. 2008; Gee et al. 2008; Jung et al. 2012). The occupation of the receptor site by a ligand is known to induce conformational change in the receptor leading to the generation of the transcription factors required for the expression of the hormone-sensitive genes. The expression of oestrogen sensitive genes through the antagonist leads to various uncontrolled physiological effects, such as hypospadia, cryochidism and cancer (Meng 2005). TCS oestrogenic, anti-oestrogenic, androgenic and anti-thyroid activities in vitro and in vivo in laboratory and aquatic animals have been demonstrated (Arancibia et al. 2009; Crofton et al. 2007; Henry and Fair 2013; Jung et al. 2012; Schiffer et al. 2014; Wallet et al. 2013) at environmentally relevant concentrations. Its anti-estrogenic effect in sheep (James et al. 2010) and anti-androgenicity in albino rats (Kumara et al. 2009) have also been demonstrated.

The observed physiological effects such as precocious puberty (Stoker et al. 2010) and carcinogenicity (Lee et al. 2012b) could be explained as a consequence of overstimulation of the receptors presumably by the high TCS concentration (Henry and Fair 2013) or as a consequence of its occupation of the ligand binding domain of the receptor (Ahn et al. 2008; Gee et al. 2008; Jung et al. 2012; Meng 2005). More data are required relating environmentally relevant TCS concentration with the reported physiological effects such as adverse reproductive effects in animals (Kumara et al. 2009).

Data appear to be accumulating supporting aetiologic role for TCS in carcinogenesis (Lee et al. 2012b; Rodricks et al. 2010; Winitthana et al. 2014; Wu et al. 2014; Yueh et al. 2014). Hepatic tumourigenesis in mice exposed to TCS has been reported to be mediated by peroxisome proliferator-activated receptor $\alpha$ (PPAR $\alpha)$ signalling pathway (Rodricks et al. 2010; Wu et al. 2014). But the work of Yueh et al. 2014 in which tumour was promoted in mice exposed to $0.1 \mathrm{~mol} / \mathrm{kg}$ TCS in drinking water for 8 months following diethylnitrosamine, (a pro-carcinogen) pre-treatment did not activate PPAR $\alpha$ in cancer promotion. Additional data would be needed to deny or confirm these contrasting reports. PPAR $\alpha$ is a ligand-activated transcription factor belonging to the nuclear receptor superfamily (Corton et al. 2014). It plays a key role in the regulation of lipid metabolism. Its activation by peroxisome proliferators is a well-characterized mode of action of hepatocarcinogenesis in rodents (Corton 2010; Corton et al. 2014). TCS hepatocarcinogenesis via PPAR $\alpha$ signalling pathway is not expected in humans because the pathway is known to be several times less active in humans than in mice (Health Canada 2012; US EPA 2008).

The report of Lu and Archer (2005) in which mammary tumour was inhibited in methylnitrosourea-treated rats fed with diets containing TCS may appear contrasting to the previous reports of tumour promoting activity of TCS but actually lends credence to the anti-oestrogenic effect of TCS since the presence of oestradiol is a requirement for developing breast cancer (Fernandez and Russo 2010; Gee et al. 2008; Henry and Fair 2013). But report from more recent studies (Lee et al. 2014) showed that TCS induced-cancer progression in MCF-7 human breast cancer cell occurred via oestrogen receptor-mediated signalling pathway implying that TCS participates through multiple mechanisms in breast cancer progression.

TCS perturbs thyroid homeostasis (Kodavanti and Curras-Collazo 2010; Veldhoen et al. 2006). It reduces circulating levels of the hormones (hypothyroxinaemia) in the exposed animals (Crofton et al. 2007; Petersen et al. 2013). The compound interferes with thyroid-mediated developmental processes of tadpoles into frogs (Fort et al. 2010, 2011). The effects are expected to be shared by all animals including humans whose cellular metabolism involves thyroid signalling pathway. Multiple mechanisms including induction of phases I and II enzymes through activation of pregnane $\mathrm{X}$ receptor are thought to be responsible for the anti-thyroid activity (Hanioka et al. 1996; Jacobs et al. 2005; Jinno et al. 1997; Paul et al. 2010). Sodium/iodide symporter is the protein normally responsible for iodide uptake but its role in this scenario has not been defined (Friesema et al. 2005; Paul et al. 2010).

TCS toxicity has been demonstrated in a number of cells including human live and cancer cells (Arancibia et al. 2009; Wallet et al. 2013) exhibiting different toxicities in different cells (Table 5). It is pro-apoptotic at $\geq 1 \mathrm{nM}$ and cytotoxic at $\geq 50 \mu \mathrm{M}$ in human choriocarcinoma-derived placental JEG-3 cell line when exposed 
Table 5 Reported triclosan (TCS) toxicities

\begin{tabular}{|c|c|c|c|c|}
\hline Cell type & TCS Concentration $(\mu \mathrm{M})$ & Exposure (h) & Toxicity & References \\
\hline Human breast cancer cells MCF-7 & $\geq 345.4$ & 120 & Proliferation (oestrogenicity) & Henry and Fair (2013) \\
\hline Human (A549) lung cancer cell & 250 & 24 & Cell membrane damage (LDH release) & Kwon et al. (2013) \\
\hline Human (H460) lung cancer cell & 10 & 24 & $\begin{array}{l}\text { Apoptotic and proliferative effect, Cell } \\
\text { membrane damage (LDH release) }\end{array}$ & Winitthana et al. (2014) \\
\hline Human PBMC & $\geq 8.6$ & 30 & $\begin{array}{l}\text { Loss of mitochondrial transmembrane } \\
\text { potential; metabolic acidosis; uncou- } \\
\text { pling of oxidative phosphorylation }\end{array}$ & Ajao et al. (2015) \\
\hline Human keratinocytes HaCaT & $\geq 8.6$ & 30 & $\begin{array}{l}\text { Loss of mitochondrial transmembrane } \\
\text { potential; necrosis }\end{array}$ & Ajao et al. (2015) \\
\hline Rat fibroblast cells (RBL) & $\geq 5$ & 1 & \multirow{2}{*}{$\begin{array}{l}\text { Uncoupling of mitochondrial oxidative } \\
\text { phosphorylation }\end{array}$} & \multirow[t]{2}{*}{ Weatherly et al. (2016) } \\
\hline Human mast cells (HMC-1.2) & $\geq 5$ & 1 & & \\
\hline Mouse JB6 Cl 41-5a cells & $\geq 8$ & $\geq 48$ & $\begin{array}{l}\text { Decreased growth; cell damage } \\
\text { (increased LDH release); necrosis }\end{array}$ & Wu et al. (2015) \\
\hline $\begin{array}{l}\text { Zebrafish (Danio rerio, AB strain) } \\
\text { embryos }\end{array}$ & 15 & 1 & $\begin{array}{l}\text { Uncoupling of mitochondrial oxidative } \\
\text { phosphorylation }\end{array}$ & Shim et al. (2016) \\
\hline $\begin{array}{l}\text { Freshwater Protozoan (Tetrahymena } \\
\text { thermophile) }\end{array}$ & $3.5 \mathrm{nM}$ & 1 & DNA damage (20 \% DNA) & Gao et al. (2015) \\
\hline Chironomus riparius Larvae. & $35 \mathrm{nM}$ & 24 & DNA damage & Martínez-Paz et al. (2013) \\
\hline
\end{tabular}

for at least $24 \mathrm{~h}$ (Honkisz et al. 2012) but may not in certain cells (Weatherly et al. 2016). Its mitochondrial uncoupling activity resulting in the loss of oxidative phosphorylation and consequently reduced ATP generation has been documented in vitro (Ajao et al. 2015, Weatherly et al. 2016) and in vivo (Shim et al. 2016) at micromolar exposure levels. TCS is a pro-oxidant (Ma et al. 2013; Tamura et al. 2012; Yueh et al. 2014). The prooxidant activity is thought to be related to the activity of 2,4-dichlorophenol (Gou et al. 2014), one of the TCS chlorinated by-products of photolysis. TCS oxidation of deoxyguanosine has been demonstrated to be inversely related to DNA methylation (Ma et al. 2013), a biomarker for tumour development and progression. The generation of reactive oxygen species is significant in cells such as $\beta$ cells known for low expression of antioxidant enzymes (Pi et al. 2007) which definitely impacts on insulin synthesis and function and ultimately diabetes pathogenesis.

TCS generally demonstrates low acute toxicity in rodents with LD50 values in excess of $\mathrm{g} / \mathrm{kg}$ body weight (US FDA 2008). There are reports that rats showed pathologic changes in liver and blood when chronically exposed for more than 13 weeks at doses higher than $150 \mathrm{ppm}$ in the diet (US FDA 2008) or in excess of $300 \mathrm{ppm} /$ day by oral gavage after 4 days (Bhargava and Leonard 1996; Crofton et al. 2007; DeSalva et al. 1989). Renal toxicity has also been reported in rats orally dosed 200 ppm/day for 6 weeks (Hassan et al. 2014). The activity of TCS in muscle $\mathrm{Ca}^{2+}$ dysregulation in mouse has been investigated (Cherednichenko et al. 2012). Exposure to TCS at $25 \mathrm{ppm}(\geq 0.09 \mathrm{~mol} / \mathrm{kg})$ for $\leq 60 \mathrm{~min}$ intraperitoneally was recorded to impair excitation-contraction coupling showing that the compound may be myotoxic.

In vivo human toxicity of TCS has not been precisely demonstrated, but detectable levels of TCS reported in the body fluids such as blood, breast milk and urine of exposed humans (Table 4) as well as in human tissues such as adipose tissue, brain, liver and nails (Table 6) fuel the conception that the compound may possibly impact human physiology. The high TCS concentrations in the tissues (Table 6) relative to the environmental concentrations (Tables 2, 3) may imply that TCS bio-accumulates and extensively distributed in human tissues.

There have been reported cases of TCS-induced allergic reactions in human subjects. Dermatitis following prolonged use of TCS-containing hand washes (Wong and Beck 2001) or when further exposed to sunlight after use (Schena et al. 2008) have been recorded. Similarly, blisters were known to have erupted in the mouth and on the lips of human subjects following prolonged use of TCS-containing toothpaste (Robertshaw and Leppard 2007). Epidemiological report has associated the increased TCS levels in urine with immune dysfunction (Clayton et al. 2011), allergic reactions and production of asthma in the children (Bertelsen et al. 2013; Spanier et al. 2014). Laboratory demonstration has shown that TCS is able to interact with human serum albumin resulting in conformational change of the protein (Chen et al. 2012a). The binding of toxicants to serum albumin can impede the transport of endogenous substances and cause conformational changes in the protein molecule, 
Table 6 Tissue distribution of triclosan in humans

\begin{tabular}{lll}
\hline Tissue & Concentration $\mathbf{( n m o l} / \mathbf{k g})$ & References \\
\hline Liver & 10.8 & Geens et al. (2012) \\
Adipose & 2.1 & Geens et al. (2012) \\
& $80.1(7.6-80.1)$ & Wang et al. (2015) \\
Brain & 0.1 & Geens et al. (2012) \\
Nails & & \\
Toes & $19.6(\mathrm{nd}-3.62 \mu \mathrm{mol} / \mathrm{kg})$ & Yin et al. (2015) \\
Fingers & $46.9(\mathrm{nd}-17.4 \mu \mathrm{mol} / \mathrm{kg})$ & \\
\hline
\end{tabular}

nd not detected

which may affect its activity or even change its physiological function (Qin et al. 2010; Soares et al. 2007). A retrospective study (Vélez et al. 2015) found that elevated TCS in the maternal urine correlated positively with diminished fecundity. Whether or not this result is related to TCS oestrogenicity (Jung et al. 2012) is presently not clear. The adverse effects of TCS in humans are thought to be via the inhibition of fatty acid synthase type 1 (FAS 1) $\left(\mathrm{IC}_{50} \geq 10 \mu \mathrm{M}\right)$ and partial inhibition of enoyl reductase of FAS 1 reactions (Liu et al. 2002). The TCS cytotoxic mechanism is being explored for drug target in cancer therapy (Sadowski et al. 2014).

\section{Fate of triclosan in environmental water}

Wastewater treatment plants (WWTPs) are not designed to remove pharmaceuticals or EDs; rather removals are based on the physical and chemical properties of the compounds. The efficiency of WWTPs is measured using parameters, such as biochemical oxygen demand (BOD) and chemical oxygen demand (COD), which do not take into account ED removal. During sewage treatment, EDs are only partially removed and are therefore frequently detected in WWTP effluents (Gomez et al. 2007; Svenson et al. 2003). Consequently, TCS is not completely removed from influents of WWTPs, (Bock et al. 2010; Snyder et al. 2007) or not at all during primary treatment (Lozano et al. 2013) and whatever remains in the aqueous phase is released into the receiving water body which may impact on the aquatic ecosystems.

TCS is stable to hydrolysis; laboratory studies showed it was stable at pH 4, 7 and 9 (US EPA 2008b). TCS is not expected to volatilize significantly given its low vapour pressure of $4 \times 10^{-6} \mathrm{~mm} \mathrm{Hg}$ at $20{ }^{\circ} \mathrm{C}$ (Ciba Speciality Chemicals 2003), however it undergoes biodegradation, photolysis and photochemical reactions, which are processes thought to be responsible for its reduction in natural waters. In conventional treatment plants, substantial amount of TCS is removed from wastewater (Table 7) but advanced treatment processes such as ozonation, photolysis and microfiltration/nanofiltration with reverse
Table 7 Triclosan removal in wastewater treatment plants (Ying and Kookana 2007)

\begin{tabular}{lc}
\hline Level of treatment & Removal rate (\%) \\
\hline Primary treatment & $2-96$ \\
Secondary treatment & \\
1. Trickling filter & $58-96$ \\
2. Activated sludge & $55-99$ \\
3. Activated sludge (simple treat) & $61-72$ \\
Tertiary treatment & $87-99$ \\
\hline
\end{tabular}

osmosis (membrane process) have achieved somewhat total removal of pharmaceuticals (Watkinson et al. 2007; Ziylan and Ince 2011) (Table 8).

In wastewater treatment plants employing membrane bioreactor, an estimated amount of over $90 \%$ mass of triclosan is expected to have been removed from the water (Wijekoon et al. 2013). The high proportion of TCS reported to have been removed in wastewater treatment plants especially those plants which employ the conventional activated sludge process may be attributed to biodegradation under aerobic conditions (Bester 2003, 2005; Heidler and Halden 2007; Ying et al. 2007). Sludge treatment plants with biological treatment process showed the highest removal of TCS (Tohidi and Cai 2016). The abundance of bacterial TCS degraders namely, ammoniaoxidizing bacteria (AOB) and Sphingopyxis strain KCY1 in activated sludge systems has been reported (Lee and Chu 2015). It is thought that ammonia monooxygenase expressed by $\mathrm{AOB}$ is responsible for TCS degradation (Roh et al. 2009) while dioxygenase in the strain KCY1 co-metabolize TCS (Lee et al. 2012b). Sphingopyxis strain KCY1, a wastewater bacterium dechlorinates TCS presumably via 2,3-dioxygenase pathway (Lee et al. 2012b) producing androgenic metabolites (Lee et al. 2012a). Trametes versicolor and Pycnoporus cinnabarinus, species of white rot fungi which grow naturally on dead wood can degrade TCS. Trametes versicolor converts TCS into $2-O-\left(2,4,4^{\prime}\right.$-trichlorodiphenyl ether)- $\beta$-D-xylopyranoside, 2 -O-(2,4,4'-trichlorodiphenyl ether)- $\beta$-D-glycopyranoside,

Table 8 Triclosan removal efficiencies (\%) in selected drinking water treatment processes [adapted from NWRI (2010), Snyder et al. (2007)]

\begin{tabular}{llll}
\hline UV $^{\mathbf{a}}$ & Chlorination $^{\mathbf{b}}$ & Chloramination $^{\mathbf{c}}$ & Ozonation $^{\mathbf{d}}$ \\
\hline $50-80$ & 80 & 80 & 95 \\
\hline
\end{tabular}

a UV dose $=40 \mathrm{~mJ} / \mathrm{cm}^{2}$

b Chlorine dose $=3 \mathrm{mg} / \mathrm{l}$, contact time $=24 \mathrm{~h}$

c Chloramine dose $=3 \mathrm{mg} / \mathrm{l}$, contact time $=24 \mathrm{~h}$

d Ozone dose $=2.5 \mathrm{mg} / \mathrm{l}$, contact time $=2 \mathrm{~min}$ 
and 2,4-dichlorophenol whereas Pycnoporus cinnabarinus converts TCS into 2,4,4'-trichloro-2'-methoxydiphenyl ether and 2-O-(2,4,4'trichlorodiphenyl ether)- $\beta$-Dglycopyranoside (Hundt et al. 2000). The metabolites have been found less toxic but of lower microbiocidal activity than TCS (NICNAS 2009). Pseudomonas putida triRY and Alcaligenes xylosoxidans subsp. denitrificans TR1 have been reported to use TCS as their sole carbon source and clear particulate TCS from agar (Hundt et al. 2000), this can be made use of in bioremediation. Recent laboratory evidence showed that maximum degradation to 2,4-dichlorophenol and $\mathrm{Cl}^{-}$by Aspergillus versicolor occurred at pH 5 and 7, depending on the substratum (Taştana and Dönmeza 2015). Minor (7 \%) transformation products of TCS biodegradation namely, monohydroxy-, dihydroxytriclosan derivatives and triclosan-O-sulfate in activated sludge have been reported recently (Chen et al. 2015). The hydroxylated derivatives have been reported earlier as products of triclosan transformation by Sphingomonas sp. PH-07 (Kim et al. 2011). The eco-toxicological significance of these minor transformation products appears obscure at this time. However, controversy still surrounds the impact of TCS on biodegradation of other co-pollutants in a given medium (Stasinakis et al. 2007; Svenningsen et al. 2011).

Chemical oxidants such as free chlorine (Canosa et al. 2005a), ozone (Chen et al. 2012b; Suarez et al. 2007), permanganate (Zhang and Huang 2003) and monochloramine (Wu et al. 2012b) are capable of degrading TCS in aquatic environment. Of all these oxidants, permanganate was reported as capable of degrading all the TCS in water under natural conditions $(\mathrm{pH}$ 8.1) and unlike other oxidants is not affected by the matrix (Wu et al. 2012b). TCS that persists in the effluents after activated sludge treatment may be chemically transformed after the discharge. Water disinfecting oxidant, sodium hypochlorite, a source of free chlorine is generally used and could chlorinate TCS, generating chlorinated derivatives such as 2,4-dichlorophenol and 2,4,6-trichlorophenol (Canosa et al. 2005a; Fiss et al. 2007). Ozonolysis appears to be the most efficient method of removing TCS in aqueous medium (Table 8). It generates, in addition to the chlorinated derivatives chloro-catechol, monohydroxy-triclosan and di-hydroxy-triclosan (Chen et al. 2012b) which are known to be more harmful than TCS to aquatic animals.

TCS is degradable under UV irradiation (photolysis) (Durán-Álvarez, et al. 2015; Lindstrom et al. 2002; Tixier et al. 2002). The UV-susceptibility in aqueous medium is related to the TCS large molar absorption coefficients (Carlson et al. 2015). Photolysis may be a significant route of TCS transformation in surface waters during summer. Laboratory evidence has shown that TCS is not appreciably photo-degraded in soils when compared to water samples (Durán-Álvarez, et al. 2015). It is believed that direct photolysis of TCS is hampered by the presence of organic substances which reflect incident photons (Hoigné et al. 1989). TCS photolysis may be enhanced in aqueous medium, by high (alkaline) $\mathrm{pH}$ in the presence of a sensitizer such as Fe(III) ions (Martínez-Zapata et al. 2013) or in the presence of surfactant in the aqueous medium which plays an accelerating role (Qiao et al. 2014). The photolysis produces 2,4-dichlorophenol and 2,4,6-trichlorophenol as stable TCS degradation products (Canosa et al. 2005b; Chen et al. 2012b; Fiss et al. 2007; Sanchez-Prado et al. 2006) while small amounts of derivatives of dioxin (2,8-dichlorodibenzodioxin (DCDD) and furan (dichlorohydroxydibenzofuran) in the aqueous medium are produced as minor products (Latch et al. 2003, 2005; Sanchez-Prado et al. 2006; Son et al. 2009). These photoproducts are more toxic than the parent (TCS) compound (Sanchez-Prado et al. 2006).

About $5 \%$ of TCS was reportedly transformed into methyltriclosan (MCS) by microbial activity (Bester 2003, 2005; Heidler and Halden 2007; Lozano et al. 2013). The final destination of TCS and its hydrophobic metabolites such as MCS is the sewage sludge (activated sludge and biosolids) through sorption wherein they are found in larger quantities than in the effluent aquatic medium (Chen et al. 2011; Heidler and Halden 2007; Kinney et al. 2008; McAvoy et al. 2002; Ying and Kookana 2007). Studies carried out on WWTP which included a Swiss plant showed that higher fraction of the TCS was adsorbed by the sludge than was present in the aqueous phase (Bester 2003; Singer et al. 2002). The work of Heidler and Halden (2007) seems to have confirmed this which reported an average of $80 \%$ of TCS bound to the particulate matters. Later reports from mass balance studies (Lozano et al. 2013; Tohidi and Cai 2016) confirmed sorption of TCS on to the particulate matters and hence its removal from the aqueous phase. The report of studies by Lozano et al. 2013 on WWTP showed that most of the TCS is removed from aqueous phase during secondary treatment and nitrification-denitrification processes and no removal takes place during primary treatment process. We suggest systematic approach in the interpretation of results from mass balance studies on TCS removal in WWTP effluents in view of the reported over-estimation when comparing with field studies (Lozano et al. 2013).

Sludge is the final destination of both TCS and its primary metabolite, MCS. Reported TCS concentrations in sludges from different plants in Germany were from $1.4 \mu \mathrm{mol}$ to $30.4 \mu \mathrm{mol} / \mathrm{kg}$ (Bester 2003) while the range in the United States was $1.8-53.9 \mu \mathrm{mol} / \mathrm{kg}$ (McAvoy et al. 2002) and $69.1 \mu \mathrm{mol}-190 \mu \mathrm{mol} / \mathrm{kg}$ in biosolids reported elsewhere in the USA (Heidler and Halden 2007) (Table 9). These values are much higher when 
compared with the results presented by Azzouz and Ballesteros (2015) (Table 10) and may be related to increased usage of TCS. Both the parent compound and its metabolite find their way to the soil when it is amended with biosolids and are retained depending on the inter-play of biotic and abiotic factors (Butler et al. 2012). Clay has the least sorption for TCS while loamy soil the highest (Wu et al. 2009) and was reportedly more pronounced at top $10 \mathrm{~cm}$ soil layer and markedly occurs in summer (Butler et al. 2012). TCS sorption to soil may reduce in alkaline environment (Wu et al. 2009) releasing TCS to the aqueous medium.

Soil samples from ten agricultural sites in Michigan previously amended with biosolids, collected over two years were shown to retain triclosan $(0.55-3.5 \mathrm{nmol} / \mathrm{kg})$ (Cha and Cupples 2009) while $0.31-24.4 \mu \mathrm{mol} / \mathrm{kg}$ triclosan was found in biosolids from three Michigan wastewater treatment plants. In certain dewatered municipal biosolids, $37.6 \mu \mathrm{mol} / \mathrm{kg}$ of TCS were reported (Gottschall et al. 2012) considered high when compared with previous values (Table 9). The practice of adding biosolids to agricultural soil has been reported in developed and developing countries (Table 10). In South Africa, six WWTP viz; Northern, Driefontein, Goudkoppie, Bushkoppie, Olifantsvlei and Ennerdale had been reported to generate a total of 91,611 tons of dry sludge per annum (Johannesburg Water 2015) which is used in composting by interested private farmers.

The concern is that biosolids may be an important source of TCS release to the environment as some $50 \%$ mass of the incoming TCS in WWTP persist and are sequestered in the biosolids (Heidler and Halden 2007). The work of Waria et al. (2011) showed that TCS could be persistent in biosolids longer in fine sand (half-life 421 days) than silty clay loam (half-life 78 days) with MCS as a primary degradation product. TCS has been detected in soils amended with biosolids 33 years after application (Xia et al. 2010). A report (Gottschall et al. 2012) detected TCS in the soil about a year after application. This raises fear that the use of biosolids in farming even after treatment (Angin and Yaganoglu 2009) may recycle TCS and/its toxic metabolites, given its potential to persist (high estimated partition coefficient $\mathrm{K}_{\mathrm{oc}}=9200$ and stability to hydrolysis) in soil, thereby exposing soil dwelling animals such as earthworms to TCS toxicity and at the same time surreptitiously increasing the human body burden of TCS via trophic levels. In anaerobic digester, exposure to oft-high level TCS concentrations has been recorded as leading to the proliferation of TCSresistant genes (McNamara et al. 2014). Application of biosolids from such digester to soil could also lead to the release of resistant bacteria to the environment (Burch et al. 2014; Fahrenfeld et al. 2014).

Some authorities (NICNAS 2009; Ying and Kookana 2007) have attempted at determining the risk quotients associated with using effluents from sludge treatment plants in irrigation. However the kinetics of TCS in sewage sludges especially biosolids have not been intensively studied which continue to leave a gap in the knowledge about the amount of TCS present in the sludge and for how long. Further intensive research is also required beamed at elucidating the kinetics of degradation

Table 9 Triclosan concentrations in wastewater sediments and sludge (Dann and Hontela 2011)

\begin{tabular}{|c|c|c|c|}
\hline Medium & Location & Concentration $(\mathrm{nmol} / \mathrm{kg})$ & References \\
\hline \multicolumn{4}{|l|}{ Sediment } \\
\hline \multirow[t]{2}{*}{ Freshwater } & Switzerland & 180 & Singer et al. (2002) \\
\hline & Spain & nd-120 & Morales et al. (2005) \\
\hline Estuarine & USA & nd-2800 & Miller et al. (2008) \\
\hline Marine & Spain & $9.3-450$ & Agüera et al. (2003) \\
\hline \multicolumn{4}{|l|}{ Sewage sludge } \\
\hline \multirow[t]{4}{*}{ Activated sludge } & USA & $1.7-53.9$ & McAvoy et al. (2002) \\
\hline & Spain & $1.4-18.7$ & Morales et al. (2005) \\
\hline & Germany & 4.1 & Bester (2003) \\
\hline & Canada & $2.1-5.0$ & Chu and Metcalfe (2007) \\
\hline \multirow[t]{4}{*}{ Biosolids } & Australia & $311-58,000$ & Ying and Kookana (2007) \\
\hline & USA & $36,300-103,600$ & $\begin{array}{l}\text { Heidler and Halden (2007), Kinney et al. (2008), } \\
\text { McClellan and Halden (2010) }\end{array}$ \\
\hline & Spain & 5210 & Morales et al. (2005) \\
\hline & Canada & $2350-43,200$ & Lee and Peart (2002), Chu and Metcalfe (2007) \\
\hline
\end{tabular}

nd not detected 
Table 10 Triclosan concentrations in agricultural soils, sewage sludge, river and pond sediments (Azzouz and Ballesteros 2015)

\begin{tabular}{llc}
\hline Medium & Location & $\begin{array}{l}\text { Concentration } \\
(\mathbf{n m o l} / \mathbf{k g})\end{array}$ \\
\hline Agricultural soils (4 points, $\mathrm{n}=12)$ & Spain & $0.028-0.1$ \\
Pond sediments (2 points, $\mathrm{n}=6)$ & Spain & $0.15-0.2$ \\
River sediments $(3$ points, $\mathrm{n}=9)$ & Spain & $0-0.18$ \\
Sewage sludge $(2$ points, $\mathrm{n}=6)$ & Spain & $0.5-0.52$ \\
\hline
\end{tabular}

products of TCS such as the dioxin derivatives known for their toxicity and persistence.

\section{Triclosan bioaccumulation and ecotoxicity}

Although TCS has the potential $\left(\log \mathrm{K}_{\mathrm{ow}}=4.76\right)$ to bioaccumulate in fatty tissues, there is no evidence in human tissues. There is evidence that TCS and its metabolites bioaccumulate in mice (Kanetoshi et al. 1992) as well as in aquatic flora and fauna including algae, inverts and fish (Adolfsson-Erici et al. 2002; Buser et al. 2006; Capdevielle et al. 2008; Coogan and La Point 2008). TCS concentrations as high as $276.3 \mu \mathrm{mol} / \mathrm{kg}$ has been reported in the bile of fish (Abramis brama) (Houtman et al. 2004). Consequently toxic endpoints attributable to TCS have been recorded in these organisms. $\mathrm{IC}_{25}$ of $0.55 \mu \mathrm{mol} / \mathrm{kg}$ affected hatchability in Zebrafish Danio rerio after 9 days exposure (Tatarazako et al. 2004). The swimming ability of fathead minnow (Pimephales promelas) was reduced when exposed to $\geq 0.52 \mu \mathrm{M}$ TCS for 7 days (Cherednichenko et al. 2012) but the exposure level used in the study might be questionable as being environmentally irrelevant because TCS levels in surface waters normally occur at nanomolar levels (Table 3 ).

Microalgae and Hydra magnipapillata are important members of prisere in aquatic ecosystem. Microalgae communities are particularly sensitive to TCS at effective concentrations of about $0.035 \mathrm{nM}$ (Wilson et al. 2009). It has been reported that at concentration $\left(\mathrm{EC}_{10}\right)$ of $3.4 \mathrm{nM}$ for $96 \mathrm{~h}$ exposure, TCS affected biomass of Anabaena flos-aquae the blue-green alga (Orvos et al. 2002). Among benthic microbial communities, TCS was found to act as a selective factor favouring the growth of cyanobacteria over algae (Drury et al. 2013). The ecotoxicological implication is that cyanobacteria produce toxins which affect zooplanktons and which in turn threatens the survival of higher members of the trophic levels (Bláha et al. 2009). Exposure of Hydra magnipapillata to TCS $(3.5 \mu \mathrm{M}$ for $4 \mathrm{~h}$ ), resulted in epidermal tissue and nematocyst damage (Park and Yeo 2012). $\mathrm{IC}_{25}$ of $0.55 \mu \mathrm{mol} / \mathrm{kg}$ affected hatchability in Zebrafish Danio rerio after 9 days exposure (Tatarazako et al. 2004). Plants and bacteria are thought to share the same fatty acids synthesis pathways; and experiments conducted with Arabidopsis family Brassicaceae have shown that enoyl-acyl carrier protein reductase is a common target of TCS (Serrano et al. 2007), probably implying that it is toxic to plants as much as to bacteria.

Methyltriclosan (MCS) is a metabolite of TCS formed by bacterial methylation (Bester 2003, 2005). Its presence in aquatic animals first pronounced by Miyazaki et al. (1984) is known to accumulate in aquatic animals than TCS presumably because of its higher partition coefficient $\left(\log \mathrm{K}_{\mathrm{ow}}=5 ; \log \mathrm{K}_{\mathrm{oc}}=4.1\right)$; compare TCS $\left(\log \mathrm{K}_{\mathrm{ow}}\right.$ : 4.2-4.8; $\left.\log \mathrm{K}_{\mathrm{oc}}: 4.3\right)$ (Chen et al. 2011). MCS concentrations in lake fish have been reported to be between 4 and $370 \mathrm{ng} / \mathrm{g}$ (Balmer et al. 2004). Higher concentrations of $520-596 \mu \mathrm{g} / \mathrm{kg}$ wet weight were reported in fresh water fish such as Cyprinus carpio (Leiker et al. 2009).

The negative impact of TCS on ecosystem is expected to have economic consequences. The United Nations Food and Agriculture Organization (FAO) reports (FAO 2014) that about 25 million tonnes of seaweeds and other algae have been harvested annually for use as food, in cosmetics and for fertilizers, and are processed into thickening agents or animal feed additives. Given the negative effects of TCS on the aquatic flora and fauna such as algae and fish, all the economic advantages such as protein supply from water resources as well as employment provision, risk shortages if TCS circulation is not properly regulated.

\section{Triclosan antimicrobial activity}

The antimicrobial activity of TCS spans against Gram positive and Gram negative non-sporulating bacteria, some fungi (Schweizer 2001), Plasmodium falciparum and Toxoplasma gondii (Al-Doori et al. 2003). At low concentrations TCS is bacteriostatic which is predicated on its inhibitory effect on the bacterial enoyl acyl carrier protein reductase (Heath et al. 1999) of fatty acid elongation pathway, whereas at higher concentrations (as found in dermatological preparations) it has bactericidal effect through membrane intercalation and triclosan-induced $\mathrm{K}^{+}$leakage (Escalada et al. 2005; Russell 2004; Villalain et al. 2001). Staphylococci, some Streptococci, some Mycobacteria, Escherichia coli and Proteus spp, Methicillin-resistant Staphylococcus aureus (MRSA) strains are all sensitive to TCS (Al-Doori et al. 2003; Suller and Russell 1999). TCS minimum inhibitory concentration of $500 \mathrm{ppb}$ as an effective bactericide in the products has been reported. Showering or bathing with $2 \%(w / w)$ TCS has been shown to be an effective concentration for the decolonization of patients whose skin is carrying MRSA (Tuffnell et al. 1987). TCS-based products have been used successfully to control MRSA (Brady et al. 1990; 
Zafar et al. 1995). Enterococci are much less susceptible than Staphylococci to TCS while Pseudomonas aeruginosa is highly resistant (Russell 2003) to it.

Microbial resistance to TCS has been reported (McMurry et al. 1998; Sanchez et al. 2005) in which membrane impermeability and efflux pump are thought to play a major mechanistic role (Gomez-Escalda et al. 2001; Sanchez et al. 2005). Studies conducted under environmentally relevant TCS concentrations produced TCS resistance (Nietch and Quinlan 2013). In the same vein, urbanization with regular discharge of TCS into the surface waters has been reported to favour TCS resistance among benthic microbial communities (Drury et al. 2013). The report of McNamara and co-workers (2014) on anaerobic digesters showed that the structure of the microbial community as well as TCS concentration is critical to the selection of resistance strains. Recent report (Gantzhorn et al. 2015) has demonstrated that mutation of one of the sigma factors (transcription initiation factor required for RNA polymerase recognition of its promoter) in combination with that of $f a b I$ (encodes the enoyl-acyl carrier protein reductase), confers highlevel microbial resistance to TCS. It however remains to be elucidated the precise role of the sigma factors, in particular which of the factors, for example rpoS or rpoD is responsible for the mutation. Microbial resistance to TCS may lead to the worst scenario of the appearance of the antibiotic insensitive bacteria the so called superbugs, as well as cross-resistance to other antibiotics such as isoniazid and ethionamide (an anti-tuberculosis prodrugs), which target Mycobacterium tuberculosis enoyl acyl carrier protein reductase (InhA) (Freundlich et al. 2009) underscoring the need to regulate TCS with a view to preventing over-use. The precise role of TCS on the selection of antibiotic resistance genes as well as multidrug resistance genes in the environment needs be determined. The concentration of TCS that is required for resistance selection in environmental communities needs be worked out too.

\section{Conclusion and future directions}

Available data on the occurrence of TCS in various environmental media, in human body and in wildlife show that the compound is not well regulated. Its uncoordinated use and careless disposal may threaten lives and the ecosystem generally. Cell based studies have shown toxicity potentials of TCS in a number of cells. Results of epidemiological studies as enunciated in this review may have supported the in vitro study reports. Cell-based assays are short-term (hours-days) and cannot be used to directly address the effect of chronic exposures. Pursuant to this widely held criticism, additional data need be generated from in vitro and in vivo studies as well as carefully designed epidemiological studies in order to make a conclusive remark on the role of the chemical in health and disease.

The detection of TCS in human fluids and tissues may not be an indicator of long term exposure as available data are insufficient to confirm its bio-accumulation in tissues (Geens et al. 2012), more so it is thought that TCS inhibits enzymes responsible for its metabolism (conjugation) (Wang et al. 2004). There is presently paucity of data on both pharmacodynamics and pharmacokinetics of TCS. Sufficient data would provide leeway in understanding the toxicity of TCS. The toxicological significance of the inhibitory effect of TCS on human fatty acid synthase (Liu et al. 2002) is not well understood though its anti-proliferative effect has been reported in some cancer cells (Honkisz et al. 2012), however administration of TCS orally to rats, dogs and baboons was reported to produce minimum toxicity in these animals (Bhargava and Leonard 1996). The presence of detectable levels of TCS in human tissues fuels the suspicion that the compound may impact negatively on human physiology. Its adverse effect on innate immunity has been reported and so are clinical reports purporting its management of human allergic skin disease (Sporik and Kemp 1997; Tan et al. 2010). Certain epidemiological studies have attempted to answer this question but sufficient consideration was not usually given to such confounding factors as inter-individual variability.

The precise role of TCS on the selection of antibiotic resistance genes as well as multidrug resistance genes in the environment needs be elucidated. The concentration of TCS that is required for resistance selection in environmental communities also needs be worked out. The relationship between TCS exposure and bio-accumulation in terrestrial animals is still inconclusive (Higgins et al. 2011) and would require expansive work which should include the kinetics of TCS conversion in the soils to its primary metabolite and uptake by such terrestrial animals as earthworms and snails which among others are important in agriculture and nutrition.

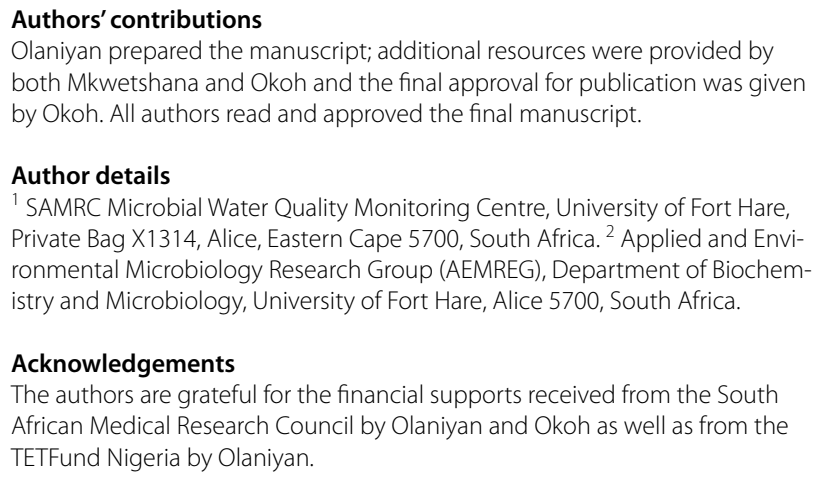

\section{Author details}

${ }^{1}$ SAMRC Microbial Water Quality Monitoring Centre, University of Fort Hare, Private Bag X1314, Alice, Eastern Cape 5700, South Africa. ${ }^{2}$ Applied and Environmental Microbiology Research Group (AEMREG), Department of Biochemistry and Microbiology, University of Fort Hare, Alice 5700, South Africa.

\section{Acknowledgements}

The authors are grateful for the financial supports received from the South African Medical Research Council by Olaniyan and Okoh as well as from the TETFund Nigeria by Olaniyan.

\section{Competing interests}

The authors declare that they have no competing interests. 
Received: 9 March 2016 Accepted: 11 September 2016 Published online: 21 September 2016

\section{References}

Adolfsson-Erici M, Petterson M, Parkkonen J, Sturve J (2002) Triclosan, a commonly used bactericide found in human milk and in the aquatic environment in Sweden. Chemosphere 46:1485-1489

Agüera A, Fernández-Alba AR, Piedra L, Mézcua M, Gómez MJ (2003) Evaluation of triclosan and biphenylol in marine sediments and urban wastewaters by pressurized liquid extraction and solid phase extraction followed by gas chromatography mass spectrometry and liquid chromatography mass spectrometry. Anal Chim Acta 480:193-205

Ahn KC, Zhao B, Chen J, Cherednichenko G, Sanmarti E, Denison MS, Lasley B, Pessah IN, Kultz D, Chang DP, Gee SJ, Hammock BD (2008) In vitro biologic activities of the antimicrobials triclocarban, its analogs, and triclosan in bioassay screens: Receptor-based bioassay screens. Environ Health Perspect 116:1203-1210

Ajao C, Andersson MA, Teplova W, Nagy S, Gahmberg CG, Andersson LC, Hautaniemi M, Kakasi B, Roivainen M, Salkinoja-Salonen M (2015) Mitochondrial toxicity of triclosan on mammalian cells. Toxicol Rep 2:624-637

Al-Doori Z, Morrison D, Edwards G, Gemmell C (2003) Susceptibility of MRSA to triclosan. J Antimicrob Chemother 51:185-186

Allmyr M, Adolfsson-Erici M, McLachlan MS, Sandborgh-Englund G (2006) Triclosan in plasma and milk from Swedish nursing mothers and their exposure via personal care products. Sci Total Environ 372:87-93

Allmyr M, Harden F, Toms LM, Mueller JF, McLachlan MS, Adolfsson-Erici M, Sandborgh-Englund G (2008) The influence of age and gender on triclosan concentrations in Australian human blood serum. Sci Total Environ 393:162-167

Allmyr M, Panagiotidis G, Sparve E, Diczfalusy U, Sandborgh-Englund G (2009) Human exposure to triclosan via toothpaste does not change CYP3A4 activity or plasma concentrations of thyroid hormones. Basic Clin Pharmacol Toxicol 105(5):339-344. doi:10.1111/j.1742-7843.2009.00455.x

Angin I, Yaganoglu AV (2009) Application of sewage sludge as a soil physical and chemical amendment. Ecoloji 19(73):39-47

Anumol T, Snyder SA (2015) Rapid analysis of trace organic compounds in water by automated online solid-phase extraction coupled to liquid chromatography-tandem mass spectrometry. Talanta 132:77-86

APUA (2011b) White paper prepared by The Alliance for the Prudent Use of Antibiotics (APUA), January 2011. http://www.tufts.edu/med/apua/consumers/personal_home_21_4240495089.pdf. Accessed 1 May 2015

Arancibia R, Caceres M, Martinez J, Smith PC (2009) Triclosan inhibits tumor necrosis factor-stimulated urikinase production in human gingival fibroblasts. J Periodontol 44:726-735

Arbuckle TE, Marro L, Davis K, Fisher M, Ayotte P, Bélanger P, Dumas P, LeBlanc $A$, Bérubé R, Gaudreau E, Provencher G, Faustman EM, Vigoren E, Ettinger AS, Dellarco AM, MacPherson S, Fraser WD (2015) Exposure to free and conjugated forms of bisphenol $\mathrm{A}$ and triclosan among pregnant women in the MIREC cohort. Environ Health Perspect 123:277-284

Aryal N, Reinhold DM (2011) Phytoaccumulation of antimicrobials from biosolids: impacts on environmental fate and relevance to human exposure. Water Res 45:5545-5552

Azzouz A, Ballesteros E (2015) Determination of 13 endocrine disrupting chemicals in environmental solid samples using microwave-assisted solvent extraction and continuous solid-phase extraction followed by gas chromatography-mass spectrometry. Anal Bioanal Chem 1-11. http://0-link.springer.com.wam.seals.ac.za/article/10.1007/s00216-0159096-1/fulltext.html. Accessed 2 Dec 2015

Azzouz A, Rascón AJ, Ballesteros E (2016) Simultaneous determination of parabens, alkylphenols, phenylphenols, bisphenol A and triclosan in human urine, blood and breast milk by continuous solid-phase extraction and gas chromatography-mass spectrometry. J Pharm Biomed Anal 119:16-26. doi:10.1016/j.jpba.2015.11.024. Accessed 2 Dec 2015

Bagley DM, Lin YJ (2000) Clinical evidence for the lack of triclosan accumulation from daily use in dentifrices. Am J Dent 13:148-152

Balmer ME, Poiger T, Droz C, Romanin K, Bergqvist PA, Müller MD, Buser HR (2004) Occurrence of methyl triclosan, a transformation product of the bactericide triclosan, in fish from various lakes in Switzerland. Environ Sci Technol 38:390-395

Benny FG, Pycke LA, Geer MD, Ovadia A, Alizee MJ, Rolf UH (2014) Human fetal exposure to triclosan and triclocarban in an urban population from Brooklyn, New York. Environ Sci Technol 48(15):8831-8838

Bertelsen RJ, Longnecker MP, Løvik M, Calafat AM, Carlsen KH, London SJ, Carlsen KCL (2013) Triclosan exposure and allergic sensitization in Norwegian children. Allergy 68:84-91

Bester K (2003) Triclosan in a sewage treatment process-balances and monitoring data. Water Res 37(16):3891-3896

Bester K (2005) Fate of triclosan and triclosan-methyl in sewage treatment plants and surface waters. Arch Environ Contam Toxicol 49(1):9-17

Bhargava HN, Leonard PA (1996) Triclosan: applications and safety. Am J Infect Control 24:209-218

Bláha L, Babica P, Maršálek B (2009) Toxins produced in cyanobacterial water blooms - toxicity and risks. Interdiscip Toxicol 2(2):36-41

Blanset DL, Zhang J, Robson MG (2007) Probabilistic estimates of lifetime daily doses from consumption of drinking water containing trace levels of N,N-diethyl-meta-toluamide (DEET), triclosan, or acetaminophen and the associated risks to human health. Hum Ecol Risk Assess 13:615-631

Bock M, Lyndall J, Barber T, Fuchsman P, Perruchon E, Capdevielle M (2010) Probabilistic application of a fugacity model to predict triclosan fate during wastewater treatment. Integr Environ Assess Manag 6:393-404

Brady L, Thomson M, Palmer M, Harkness J (1990) Successful control of endemic MRSA in a cardiothoracic surgical unit. Med J Aust 152:240-245

Burch TR, Sadowsky MJ, LaPara TM (2014) Fate of antibiotic resistance genes and class 1 integrons in soil microcosms following the application of treated residual municipal wastewater solids. Environ Sci Technol. doi:10.1021/es501098g

Buser HR, Balmer ME, Schmid P, Kohler M (2006) Occurrence of UV filters 4-methylbenzylidene camphor and octocrylene in fish from various Swiss rivers with inputs from wastewater treatment plants. Environ Sci Technol 40(5):1427-1431

Butler E, Whelan MJ, Sakrabani R, van Egmond R (2012) Fate of triclosan in field soils receiving sewage sludge. Environ Pollut 167:101-109

Calafat AM, Ye X, Wong LY, Reidy JA, Needham LL (2008) Urinary concentrations of triclosan in the U.S. Population: 2003-2004. Environ Health Perspect 116:303-307

Canada (2007) Food and drugs regulations: cosmetic regulations, C.R.C., C. 869. http://lawslois.justice.gc.ca/eng/regulations/C.R.C.,_c._869/FullText. html. Accessed 7 Sept 2015

Canosa P, Morales S, Rodríguez I, Rubí E, Cela R, Gómez M (2005a) Aquatic degradation of triclosan and formation of toxic chlorophenols in presence of low concentrations of free chlorine. Anal Bioanal Chem 383:1119-1126

Canosa P, Rodriguez I, Rubi E, Cela R (2005b) Optimization of solid-phase microextraction conditions for the determination of triclosan and possible related compounds in water samples. J Chromatogr A 1072(1):107-115

Capdevielle M, Egmond RV, Whelan M, Versteeg D, Hofmann-Kamensky M, Inauen J, Cunningham V, Voltering D (2008) Consideration of exposure and species sensitivity of triclosan in the freshwater environment. Integr Environ Assess Manag 4(1):15-23

Carlson JC, Stefan MI, Parnis JM, Metcalfe CD (2015) Direct UV photolysis of selected pharmaceuticals, personal care products and endocrine disruptors in aqueous solution. Water Res 84:350-361

Cha J, Cupples AM (2009) Detection of the antimicrobials triclocarban and triclosan in agricultural soils following land application of municipal biosolids. Water Res 43:2522-2530

Chedgzoy P, Winckle G, Heard CM (2002) Triclosan: release from transdermal adhesive formulations and in vitro permeation across human epidermal membranes. Int J Pharm 235:229-236

Chen X, Nielsen JL, Furgal K, Liu Y, Lolas IB, Bester K (2011) Biodegradation of triclosan and formation of methyl-triclosan in activated sludge under aerobic conditions. Chemosphere 84:452-456

Chen J, Zhou X, Zhang Y, Zi Y, Qian Y, Lin S (2012a) Binding of triclosan to human serum albumin: insight into the molecular toxicity of emerging contaminant. Environ Sci Pollut Res 19(7):2528-2536

Chen XJ, Richard J, Liu YL, Dopp E, Tuerk J, Bester K (2012b) Ozonation products of triclosan in advanced wastewater treatment. Water Res 46(7):2247-2256 
Chen X, Casas ME, Nielsen JL, Wimmer R, Bester K (2015) Identification of triclosan-O-sulfate and other transformation products of triclosan formed by activated sludge. Sci Total Environ 505:39-46

Cherednichenko G, Zhang R, Bannister RA, Timofeyev V, Li N, Fritsch EB, Feng W, Barrientos GC, Schebb NH, Hammock BD, Beam KG, Chiamvimonvat N, Pessah IN (2012) Triclosan impairs excitation-contraction coupling and $\mathrm{Ca}^{2+}$ dynamics in striated muscle. Proc Natl Acad Sci USA 109(35):14158-14163. doi:10.1073/pnas.1211314109

Chi GT, Churchley J, Huddersman KD (2013) Pilot-scale removal of trace steroid hormones and pharmaceuticals and personal care products from municipal wastewater using a heterogeneous fenton's catalytic process. Int J Chem Eng Article ID 760915. doi:10.1155/2013/760915

Chu S, Metcalfe CD (2007) Simultaneous determination of triclocarban and triclosan in municipal biosolids by liquid chromatography tandem mass spectrometry. J Chromatogr 1164:212-218

Ciba Speciality Chemicals (2003) Ciba Irgasan DP 300, Irgacare MP_Toxicological and ecological data. Pub. No. PC.PH.TOX.0301.e.02

Clayton EMR, Todd M, Dowd JB, Aiello AE (2011) The impact of bisphenol A and triclosan on immune parameters in the U.S. population, NHANES 2003-2006. Environ Health Perspect 119:390-396

Colborn T, vom Saal FS, Soto AM (1993) Developmental effects of endocrinedisrupting chemicals in wildlife and humans. Environ Health Perspect 101(5):378-384

Coogan MA, La Point TW (2008) Snail bioaccumulation of triclocarban, triclosan, and methyltriclosan in a North Texas, USA, stream affected by wastewater treatment plant runoff. Environ Toxicol Chem 27(8):1788-1793

Corton JC (2010) Mode of action analysis and human relevance of liver tumors induced by PPARa activation. In: Hsu CH, Stedeford T (eds) Cancer risk assessment: chemical carcinogenesis, hazard evaluation, and risk quantification. Wiley, Hobokon, pp 438-481

Corton JL, Cunningham ML, Hummer BT, Lau CB, Meek JM, Peters JM, Popp JA, Rhomberg L, Seed J, Klaunig JE (2014) Mode of action framework analysis for receptor-mediated toxicity: the peroxisome proliferator-activated receptor alpha (PPARalpha) as a case study. Crit Rev Toxicol 44:1-49

Crofton KM, Paul KB, DeVito MJ, Joan M, Hedge JM (2007) Short-term in vivo exposure to the water contaminant triclosan: evidence for disruption of thyroxine. Environ Toxicol Pharmacol 24:194-197

Dann AB, Hontela A (2011) Triclosan: environmental exposure, toxicity and mechanisms of action. J Appl Toxicol 31(4):285-311

Dayan AD (2007) Risk assessment of triclosan (Irgasan R) in human breast milk. Food Chem Toxicol 45:125-129

DeSalva SJ, Kong BM, Lin YJ (1989) Triclosan: a safety profile. Am J Dent 2:185-196

Dhillon GS, Kaur S, Pulicharla A, Brar SK, Cledón M, Verma M, Surampalli RY (2015) Triclosan: current status, occurrence, environmental risks and bioaccumulation potential. Int J Environ Res Public Health 12(5):5657-5684

Drury B, Scott J, Rosi-Marshall EJ, Kelly JJ (2013) Triclosan exposure increases triclosan resistance and influences taxonomic composition of benthic bacterial communities. Environ Sci Technol 47:8923-8930

Durán-Álvarez JC, Prado B, González D, Sánchez Y, Jiménez-Cisneros B (2015) Environmental fate of naproxen, carbamazepine and triclosan in wastewater, surface water and wastewater irrigated soil-results of laboratory scale experiments. Sci Total Environ 538:350-362

Escalada MG, Russell AD, Maillard JY, Ochs D (2005) Triclosan-bacteria interactions: single or multiple target sites? Lett Appl Microbiol 41:476-481

European Commission (2010) Council directive 76/768/EEC of 27 July 1976 on the approximation of the laws of the Member States relating to cosmetic products. Annex Vl: List of preservatives which cosmetic products may contain. http://eurlex.europa.eu/LexUriServ/LexUriServ.do?uri=CO NSLEG:1976L0768:20100301:en.pdf

Fahrenfeld N, Knowlton K, Krometis LA, Hession WC, Xia K, Lipscomb E, Libuit K, Green BL, Pruden A (2014) Effect of manure application on abundance of antibiotic resistance genes and their attenuation rates in soil: field-scale mass balance approach. Environ Sci Technol 48(5):2643-2650

Fair PA, Lee HB, Adams J, Darling C, Pacepavicius G, Alaee M, Bossart GD, Henry N, Muir D (2009) Occurrence of triclosan in plasma of wild Atlantic bottlenose dolphins (Tursiops truncatus) and in their environment. Environ Pollut 157(8-9):2248-2254
Fang JL, Vanlandingham M, da Costa GG, Beland FA (2014) Absorption and metabolism of triclosan after application to the skin of B6C3F1 mice. Environ Toxicol (Epub ahead of print). www.ncbi.nlm.nih.gov/pubmed. Accessed 29 Aug 2015

FAO (2014) The state of world fisheries and aquaculture 2014 Rome. www.fao. org/3/a-i3720e.pdf. Accessed 1 Nov 2015

Fernandez SV, Russo J (2010) Estrogen and xenoestrogens in breast cancer. Toxicol Pathol 38:110-122

Fiss EM, Rule KL, Vikesland PJ (2007) Formation of chloroform and other chlorinated by-products by chlorination of triclosan-containing antibacterial products. Environ Sci Technol 41(7):2387-2394

Foran CM, Bennett ER, Benson WH (2000) Developmental evaluation of a potential non-steroidal estrogen: triclosan. Mar Environ Res 50:153-156

Fort DJ, Rogers RL, Gorsuch JW, Navarro LT, Peter R, Plautz JR (2010) Triclosan and anuran metamorphosis: no effect on thyroid-mediated metamorphosis in Xenopus laevis. Toxicol Sci 113(2):392-400

Fort DJ, Mathis MB, Hanson W, Fort CE, Navarro LT, Peter R, Buche C, Unger S, Pawlowski S, Plautz JR (2011) Triclosan and thyroid-mediated metamorphosis in anurans: differentiating growth effects from thyroid-driven metamorphosis in Xenopus laevis. Toxicol Sci 121(2):292-302

Freundlich JS, Wang F, Vilchèze C, Gulten G, Langley R, Schiehser GA, Jacobus DP, Jacobs WR Jr, Sacchettini JC (2009) Triclosan derivatives: towards potent inhibitors of drug sensitive and drug-resistant Mycobacterium tuberculosis. ChemMedChem 4(2):241-248. doi:10.1002/ cmdc.200800261

Friesema EC, Jansen J, Milici C, Visser TJ (2005) Thyroid hormone transporters. Vitam Horm 70:137-167

Gantzhorn MR, Olsen JE, Thomsen LE (2015) Importance of sigma factor mutations in increased triclosan resistance in Salmonella Typhimurium. BMC Microbiol 15:105. http://www.biomedcentral.com/1471-2180/15/105. Accessed 29 Oct 2015

Gao L, Yuan T, Cheng P, Bai Q, Zhou C, Ao J, Wang W, Zhang H (2015) Effects of triclosan and triclocarban on the growth inhibition, cell viability, genotoxicity and multixenobiotic resistance responses of Tetrahymena thermophila. Chemosphere 139:434-440. doi:10.1016/j. chemosphere.2015.07.059

Gee RH, Charles A, Taylor N, Darbre PD (2008) Oestrogenic and androgenic activity of triclosan in breast cancer cells. J Appl Toxicol 28(1):78-91

Geens T, Roosens L, Neels H, Covaci A (2009) Assessment of human exposure to bisphenol-A, triclosan and tetrabromobisphenol-A through indoor dust intake in Belgium. Chemosphere 76(6):755-760

Geens T, Neels H, Covaci A (2012) Distribution of bisphenol-A, triclosan and $\mathrm{n}$-nonylphenol in human adipose tissue, liver and brain. Chemosphere 87(7):796-802

Glassmeyer ST, Furlong ET, Kolpin DW, Cahill JD, Zaugg SD, Werner SL, Meyer MT, Kryak DD (2005) Transport of chemical and microbial compounds from known wastewater discharges: potential for use as indicators of human fecal contamination. Environ Sci Technol 39:5157-5169

Golden RJ, Noller KL, Titus-Ernstoff L, Kaufman RH, Mittendorf R, Reese EA (1999) Environmental endocrine modulators and human health: an assessment of the biological evidence. Crit Rev Toxicol 28:109-227

Gomez E, Wang X, Dagnino S, Leclercq M, Escande A, Casellas C, Picot B, Fenet $\mathrm{H}$ (2007) Fate of endocrine disrupters in waste stabilization pond systems. Water Sci Technol 55(11):157-163

Gomez-Escalda M, Maillard JY, Russell AD (2001) Effects of triclosan-sensitive and resistant strains of Gram-negative bacteria. Soc Appl Microbiol 30:9-12

Gottschall N, Topp E, Metcalfe C, Edwards M, Payne M, Kleywegt S, Russell P, Lapen DR (2012) Pharmaceutical and personal care products in groundwater, subsurface drainage, soil, and wheat grain, following a high single application of municipal biosolids to a field. Chemosphere 87:194-203

Gou N, Yuan S, Lan J, Gao C, Alshawabkeh AN, Gu AZ (2014) A quantitative toxicogenomics assay reveals the evolution and nature of toxicity during the transformation of environmental pollutants. Environ Sci Technol 48(15):8855-8863

Halden RU, Paul DH (2005) Co-occurence of triclocarban and triclosan in U.S. water resources. Environ Sci Technol 39:1420-1426 
Hanioka N, Omae E, Nishimura T, Jinno H, Onodera S, Yoda R, Ando M (1996) Interaction of 2,4,4-trichloro-2-hydroxydiphenyl ether with microsomal cytochrome $\mathrm{P} 450$-dependent monooxygenases in rat liver. Chemosphere 33:265-276

Hanioka N, Jinno H, Nishimura T, Ando M (1997) Effect of 2,4,4'-trichloro-21'hydroxydiphenyl ether on cytochrome P450 enzymes in the rat liver. Chemosphere 34:719-730

Hassan ZA, Abd El-Haleem MR, Mansour GN (2014) Effect of triclosan on the renal cortex of adult male albino rats and the possible protective role of ellagic acid: histological and biochemical study. J Cytol Histol 5:6

Health Canada and Environment Canada (2012) Preliminary assessment-triclosan. http://www.ec.gc.ca/ese-ees/6EF68BEC-5620-4435-87299B91C57A9FD2/Triclosan_EN.pdf. Accessed 29 May 2016

Heath RJ, Rubin JR, Holland DR, Zhang E, Snow ME, Rock CO (1999) Mechanism of triclosan inhibition of bacterial fatty acid synthesis. J Biol Chem 274:11110-11114

Heidler J, Halden RU (2007) Mass balance assessment of triclosan removal during conventional sewage treatment. Chemosphere 66(2):362-369

Helbing CC, van Aggelen G, Veldhoen N (2011) Triclosan affects thyroid hormone dependent metamorphosis in anurans. Toxicol Sci 119:417-418

Henry ND, Fair PA (2013) Comparison of in vitro cytotoxicity, estrogenicity and anti-estrogenicity of triclosan, perfluorooctane sulfonate and perfluorooctanoic acid. J Appl Toxicol 33:265-272. doi:10.1002/jat.1736

Higgins CP, Paesani ZJ, Chalew TEA, Halden RU, Hundal LS (2011) Persistence of triclocarban and triclosan in soils after land application of biosolids and bioaccumulation in Eisenia foetida. Environ Toxicol Chem 30(3):556-563

Hoigné J, Faust BC, Haag WR, Zepp RG (1989) Aquatic humic substances. American Chemical Society, Washington, DC

Hollander D (1997) Environmental effects on reproductive health: the endocrine disruption hypothesis. Fam Plann Perspect 29(2):82-89

Honkisz E, Zieba-Przybylska D, Wojtowicz AK (2012) The effect of triclosan on hormone secretion and viability of human choriocarcinoma JEG-3 cells. Reprod Toxicol 34:385-392

Houtman CJ, Van Oostveen AM, Brouwer A, Lamoree MH, Legler J (2004) Identification of estrogenic compounds in fish bile using bioassay directed fractionation. Environ Sci Technol 38(23):6415-6423

Hovander L, Malmberg T, Athanasiadou M, Athanassiadis I, Rahm S, Bergman A, Wehler EK (2002) Identification of hydroxylated PCB metabolites and other phenolic halogenated pollutants in human blood plasma. Arch Environ Contam Toxicol 42:105-117

Huang H, Du G, Zhang W, Hu J, Wu DI, Song L, Xia Y, Wang X (2014) The in vitro estrogenic activities of triclosan and triclocarban. J Appl Toxicol. doi:10.1002/jat.30012

Hundt K, Martin D, Hammer E, Jonas U, Kinderman MK, Schauer F (2000) Transformation of triclosan by Trametes versicolor and Pycnoporus cinnabarinus. Appl Environ Microbiol 66(9):4157-4160

Ishibashi H, Matsumura N, Hirano M, Matsuoka M, Shiratsuchi H, Ishibashi Y, Takao Y, Arizono K (2004) Effects of triclosan on the early life stages and reproduction of medaka Oryzias latipes and induction of hepatic vitellogenin. Aquat Toxicol 67:167-179

Jacobs MN, Nolan GT, Hood SR (2005) Lignans, bacteriocides and organochlorine compounds activate the human pregnane $\mathrm{X}$ receptor (PXR). Toxicol Appl Pharmacol 209:123-133

James MO, Li W, Summerlot DP, Rowland-Faux L, Wood CE (2010) Triclosan is a potent inhibitor of estradiol and estrone sulfonation in sheep placenta. Environ Int 36:942-949

Jinno H, Hanioka N, Onodera S, Nishimura T, Ando M (1997) Irgasan DP 300 (5-chloro-2-(2,4-dichlorophenoxy)-phenol) induces cytochrome P450s and inhibits haem biosynthesis in rat hepatocytes cultured on Matrigel. Xenobiotica 27:681-692

Johannesburg Water (2015) Corporate profile, Johannesburg Water (Pty) Limited. http://www.johannesburgwater.co.za. Accessed 7 Nov 2015

Jung EM, An BS, Choi KC, Jeung EB (2012) Potential estrogenic activity of triclosan in the uterus of immature rats and rat pituitary $\mathrm{GH} 3$ cells. Toxicol Lett 208:142-148

Kanetoshi A, Katsura E, Ogawa H, Ohyama T, Kaneshima H, Miura T (1992) Acute toxicity, percutaneous absorption and effects on hepatic mixed function oxidase activities of 2,4,4i-trichloro-2i-hydroxydiphenyl ether (Irgasan DP300) and its chlorinated derivatives. Arch Environ Contam Toxicol 23:91-98
Kantiani L, Farré M, Asperger D, Fernando Rubio F, González S, López de Alda MJ, Petrović M, Shelver WL, Barcelo D (2008) Triclosan and methyltriclosan monitoring studyin the northeast of Spain using a magnetic particle enzyme immunoassay and confirmatory analysis by gas chromatography-mass spectrometry. J Hydrol 361:1-9

Karnjanapiboonwong A, Suski JG, Shah AA, Cai Q, Morse AN, Anderson TA (2011) Occurrence of PPCPs at a wastewater treatment plant and in soil and groundwater at a land application site. Water Air Soil Pollut 216:257-273

Kim YM, Murugesan K, Schmidt S, Bokare V, Jeon JR, Kim EJ, Chang YS (2011) Triclosan susceptibility and co-metabolism-a comparison for three aerobic pollutant-degrading bacteria. Bioresour Technol 102:2206-2212

Kinney CA, Furlong ET, Kolpin DW, Burkhardt MR, Steven D, Zaugg SD, Werner SL, Bossio JP, Benotti MJ (2008) Bioaccumulation of pharmaceuticals and other anthropogenic waste indicators in earthworms from agricultural soil amended with biosolid or swine manure. Environ Sci Technol 42(6):8

Kirk-Othmer Encyclopedia of Chemical Technology (1993) 4th ed. vol 1. Wiley, New York, V7, 1026

Kodavanti PRS, Curras-Collazo MC (2010) Neuroendocrine actions of organohalogens: thyroid hormones, arginine vasopressin, and neuroplasticity. Front Neuroendocrinol 31(4):479-496

Kolpin DW, Furlong ET, Meyer MT, Thurman EM, Zaugg SD, Barber LB, Buxton HT (2002) Pharmaceuticals, hormones, and other organic wastewater contaminants in U.S. streams, 1999-2000: a national reconnaissance. Environ Sci Technol 36:1202-1211

Kumar KS, Priya SM, Peck AM, Sajwan KS (2010) Mass loadings of triclosan and triclocarban from four wastewater treatment plants to three rivers and landfill in Savannah, Georgia, USA. Arch Environ Contam Toxicol 58:275-285

Kumara V, Chakrabortya A, Kural MR, Roy P (2009) Alteration of testicular steroidogenesis and histopathology of reproductive system in male rats treated with triclosan. Reprod Toxicol 27(2):177-185

Kwon JT, Seo GB, Kim HM, Shim I, Lee B, Jung JY, Kim P, Choi K (2013) Evaluation of comparative cytotoxicity of spray-type chemicals used in household products. Mol Cell Toxicol 9:51-56

Larsson K, Björklund KL, Palm B, Wennberg M, Kaj L, Lindh CH, Jönsson BAG, Berglund M (2014) Exposure determinants of phthalates, parabens, bisphenol $A$ and triclosan in Swedish mothers and their children. Environ Int 73.323-333

Latch DE, Packer JL, Arnold WA, McNeill K (2003) Photochemical conversion of triclosan to 2,8-dichlorodibenzo-p-dioxin in aqueous solution. J Photochem Photobiol A 158:63-66

Latch DE, Packer JL, Stender BL, VanOverbeke J, Arnold WA, McNeill K (2005) Aqueous photochemistry of triclosan: formation of 2,4-dichlorophenol, 2,8-dichlorodibenzo-p-dioxin, and oligomerization products. Environ Toxicol Chem 24(3):517-525

Lee DG, Chu KH (2015) Abundances of triclosan-degrading microorganisms in activated sludge systems. Environ Eng Res 20(1):105-109

Lee HB, Peart TE (2002) Organic contaminants in Canadian municipal sewage sludge. Part I. Toxic or endocrine-disrupting phenolic compounds. Water Qual Res J Can 37:681-696

Lee DG, Zhao F, Rezenom YH, Russell DH, Chu KH (2012a) Biodegradation of triclosan by a wastewater microorganism. Water Res 46(13):4226-4234

Lee H, Park M, Yi B, Choi K (2012b) Octylphenol and triclosan induced proliferation of human breast cancer cells via an estrogen receptor-mediated signaling in vitro. Endocrine Abstracts 29, P749 http://www.endocrineabstracts.org/ea/0029/ea0029p749.htm. Accessed Aug 112015

Lee HR, Hwang KA, Nam KH, Kim HC, Choi KC (2014) Progression of breast cancer cells was enhanced by endocrine disrupting chemicals, triclosan and octylphenol, via an estrogen receptor-dependent signaling pathway in cellular and mouse xenograft models. Chem Res Toxicol 27:834-842. doi:10.1021/t×5000156

Leiker TJ, Abney SR, Goodbred SL, Rosen MR (2009) Identification of methyl triclosan and halogenated analogues in male common carp (Cyprinus carpio) from Las Vegas Bay and semipermeable membrane devices from Las Vegas Wash, Nevada. Sci Total Environ 407(6):2102-2114

Li X, Ying GG, Su HC, Yang XB, Wang L (2010) Simultaneous determination and assessment of 4-nonylphenol, bisphenol A and triclosan in tap water, bottled water and baby bottles. Environ Int 36:557-562 
Li X, Ying GG, Zhao JL, Chen ZF, Lai HJ, Su HC (2013) 4-Nonylphenol, bisphenol$A$ and triclosan levels in human urine of children and students in China, and the effects of drinking these bottled materials on the levels. Environ Int 52:81-86

Lin YJ (2000) Buccal absorption of triclosan following topical mouth rinse application. Am J Dent 13(4):215-217

Lindstrom A, Buerge IJ, Poiger T, Bergovist PA, Muller MD, Buser HR (2002) Occurrence and environmental behaviour of the bactericide triclosan and its methyl derivative in surface waters and in wastewater. Environ SciTechnol 36:2322-2329

Liu B, Wang Y, Fillgrove KL, Anderson VE (2002) Triclosan inhibits enoyl-reductase of type I fatty acid synthase in vitro and is cytotoxic to MCF-7 and SKBr-3 breast cancer cells. Cancer Chemother Pharmacol 49:187-193. doi:10.1007/s00280-001-0399-x

Loraine GA, Pettigrove ME (2006) Seasonal variations in concentrations of pharmaceuticals and personal care products in drinking water and reclaimed wastewater in southern California. Environ Sci Technol 40:687-695

Lozano N, Rice CP, Ramirez M, Torrents A (2013) Fate of triclocarban, triclosan and methyltriclosan during wastewater and biosolids treatment processes. Water Res 47(13):4519-4527

Lu S, Archer MC (2005) Fatty acid synthase is a potential molecular target for the chemoprevention of breast cancer. Carcinogenesis 26:153-157

Ma H, Zheng L, Li Y, Pan S, Hu J, Yu Z, Zhang G, Sheng G, Fu J (2013) Triclosan reduces the levels of global DNA methylation in HepG2 cells. Chemosphere 90:1023-1029

Maclsaac JK, Gerona RR, Blanc PD, Apatira L, Friesen MW, Cop-polino M, Janssen S (2014) Health care worker exposures to the antibacterial agent triclosan. J Occup Environ Med 56:834-839

Martínez-Paz P, Morales M, Martínez-Guitarte JL, Morcillo G (2013) Genotoxic effects of environmental endocrine disruptors on the aquatic insect Chironomus riparius evaluated using the comet assay. Mutat Res 758:41-47

Martínez-Zapata M, Aristizábal C, Peñuela G (2013) Photodegradation of the endocrine-disrupting chemicals $4 \mathrm{n}$-nonylphenol and triclosan by simulated solar UV irradiation in aqueous solutions with $\mathrm{Fe}$ (III) and in the absence/presence of humic acids. J Photochem Photobiol A 251:41-49

McAvoy DC, Schatowitz B, Jacob M, Hauk A, EckhoffWS (2002) Measurement of triclosan in wastewater treatment systems. Environ Toxicol Chem 21(7):1323-1329

McClellan K, Halden RU (2010) Pharmaceuticals and personal care products in archived U.S. biosolids from the 2001 EPA national sewage sludge survey. Water Res 44(2):658-668

McMurry LM, Oethinger M, Levy SB (1998) Overexpression of marA, soxS, or acrAB produces resistance to triclosan in laboratory and clinical strains of Escherichia coli. FEMS Microbiol Lett 166:305-309

McNamara PJ, LaPara TM, Novak PJ (2014) The impacts of triclosan on anaerobic community structures, function, and antimicrobial resistance. Environ Sci Technol 48:7393-7400

Meng Z (2005) Removal of estrogenic pollutants from contaminated water. Environ Sci Technol 39:8958-8962

Miller TR, Heidler J, Chillrud SN, Delaquil A, Ritchie JC, Mihalic JN, Bopp R, Halden RU (2008) Fate of triclosan and evidence for reductive dechlorination of triclocarban in estuarine sediments. Environ Sci Technol 42(12):4570-4576

Miyazaki T, Yamagishi T, Matsumoto M (1984) Residues of 4-chloro-1-(2,4dichlorophenoxy)-2-methoxybenzene(triclosanmethyl) in aquatic biota. Bull Environ Contam Toxicol 32(2):227-232

Morales S, Canosa P, Rodriguez I, Rubi E, Cela R (2005) Microwave assisted extraction followed by gas chromatography with tandem mass spectrometry for the determination of triclosan and two related chlorophenols in sludge and sediments. J Chromatogr A 1082(2):128-135

Moss T, Howes D, Williams F (2000) Percutaneous penetration and dermal metabolism of triclosan (2,4,4'-trichloro-2'-hydroxydiphenyl ether). Food Chem Toxicol 38:361-370

NICNAS (2009) National industrial chemicals notification and assessment scheme. Triclosan. Priority Existing Chemical Assessment Report No. 30 Australian Government Department of Health and Aging. http://www. nicnas.gov.au/communications/publications/chemical-assessments and www.nicnas.gov.au/chemical-information/pec-assessments, January 2009. Accessed 11 May 2016
Nietch C, Quinlan E (2013) Effects of a chronic lower range of triclosan exposure on a stream mesocosm community. Environ Toxicol Chem 32:2874-2887

NWRI (2010) Source, fate, and transport of endocrine disruptors, pharmaceuticals, and personal care products in drinking water sources in California. In: Guo YC, Krasner SW, Fitzsimmons S, Woodside G, Yamachika N (eds) National Water Research Institute Fountain Valley, California. http:// www.nwri-usa.org/epublications.htm. Accessed 16 May 2016

Orvos DR, Versteeg DJ, Inauen J, Capdevielle M, Rothenstein A, Cunningham V (2002) Aquatic toxicity of triclosan. Environ Toxicol Chem 21(7):1338-1349

Padhye LP, Yao H, Francis T, Kung'u FT, Huang CH (2014) Year-long evaluation on the occurrence and fate of pharmaceuticals, personal care products, and endocrine disrupting chemicals in an urban drinking water treatment plant. Water Res 51(15):266-276

Pannu MW, Toor GS, O'Connor GA, Wilson PC (2012) Toxicity and bioaccumulation of biosolids-borne triclosan in food crops. Environ Toxicol Chem 31:2130-2137

Park HG, Yeo MK (2012) The toxicity of triclosan, bisphenol A, bisphenol A diglycidyl ether to the regeneration of cnidarian, Hydra magnipapillata. Mol Cell Toxicol 8:209-216

Paul KB, Hedge JM, Devito MJ, Crofton K (2010) Developmental triclosan exposure decreases maternal and neonatal thyroxine in rats. Environ Toxicol Chem 29(12):2840-2844

Perencevich EN, Wong MT, Harris AD (2001) National and regional assessment of the antibacterial soap market: a step toward determining the impact of prevalent antibacterial soaps. Am J Infect Control 29:281-283

Perez AL, De Sylor MA, Slocombe AJ, Lew MG, Unice KM, Donovan EP (2013) Triclosan occurrence in freshwater systems in the United States (1999-2012): a meta-analysis. Environ Toxicol Chem 32(7):1479-1487

Petersen MA, Boberg J, Vinggaard AM, Christiansen S, Hass U (2013) Triclosan exposure reduces thyroxine levels in pregnant and lactating rat dams and in directly exposed offspring. Food Chem Toxicol 59:534-540

Pi J, Bai Y, Zhang Q, Wong V, Floering LM, Daniel K, Reece JM, Deeney JT, Andersen ME, Corkey BE, Collins S (2007) Reactive oxygen species as a signal in glucose-stimulated insulin secretion. Diabetes 56:1783-1791

Pintado-Herrera MG, González-Mazo E, Lara-Martín PA (2014) Atmospheric pressure gas chromatography-time-of-flight-mass spectrometry (APGC-ToF-MS) for the determination of regulated and emerging contaminants in aqueous samples after stir bar sorptive extraction (SBSE). Anal Chim Acta 851:1-13

Prosser RS, Sibley PK (2015) Human health risk assessment of pharmaceuticals and personal care products in plant tissue due to biosolids and manure amendments, and wastewater irrigation. Environ Int 75:223-233

Qiao X, Zheng X, Xie Q, Yang X, Xiao J, Xue W, Chen J (2014) Faster photodegradation rate and higher dioxin yield of triclosan induced by cationic surfactant CTAB. J Hazard Mater 275:210-214

Qin PF, Liu RT, Pan XR, Fang XY, Mou Y (2010) Impact of carbon chain length on binding of perfluoroalkyl acids to bovine serum albumin determined by spectroscopic methods. J Agric Food Chem 58:5561-5567

Queckenberg C, Meins J, Wachall B, Doroshyenko O, Tomalik-Scharte D, Bastian B, Abdel-Tawab M, Fuhr U (2010) Absorption, pharmacokinetics, and safety of triclosan after dermal administration. Antimicrob Agents Chemother 54(1):570-572

Reiss R, Mackay N, Habig C, Griffin J (2002) An ecological risk assessment for triclosan in lotic systems following discharge from wastewater treatment plants in the United States. Environ Toxicol Chem 21(11):2483-2492

Robertshaw H, Leppard B (2007) Contact dermatitis to triclosan in toothpaste. Contact Dermat 57:383-384

Rodricks JV, Swenberg JA, Borzelleca JF, Maronpot RR, Shipp AM (2010) Triclosan: a critical review of the experimental data and development of margins of safety for consumer products. Crit Rev Toxicol 40:422-484

Roh H, Subramanya N, Zhao F, Yu CP, Sandt J, Chu KH (2009) Biodegradation potential of wastewater micropollutants by ammonia-oxidizing bacteria. Chemosphere 77:1084-1089

Rüdel H, Böhmer W, Müller M, Fliedner A, Ricking M, Teubner D, SchröterKermani C (2013) Retrospective study of triclosan and methyl-triclosan residues in fish and suspended particulate matter: results from the German Environmental Specimen Bank. Chemosphere 91 (11):1517-1524

Russell AD (2003) Similarities and differences in the responses of microorganisms to biocides. J Antimicrob Chemother 52:750-763 
Russell AD (2004) Whither triclosan? J Antimicrob Chemother 53:693-695 Sadowski MC, Pouwer RH, Gunter JH, Lubik AA, Quinn RJ, Nelson CC (2014) The fatty acid synthase inhibitor triclosan: repurposing an anti-microbial agent for targeting prostate cancer. Oncotarget 5(19):9362-9381. doi:10.18632/oncotarget.2433

Sanchez P, Moreno E, Martinez JL (2005) The biocide triclosan selects Stenotrophomonas maltophilia mutants that overproduce the SmeDEF multidrug efflux pump. Antimicrob Agents Chemother 49:781-782

Sanchez-Prado L, Llompart M, Lores M, García-Jares C, Bayona JM, Cela R (2006) Monitoring the photochemical degradation of triclosan in wastewate by UV light and sunlight using solid-phase microextraction. Chemosphere 65:1338-1347

Sandborgh-Englund G, Adolfsson-Erici M, Odham G, Ekstrand J (2006) Pharmacokinetics of triclosan following oral ingestion in humans. J Toxicol Environ Health Part A 69(20):1861-1873

Schena D, Papagrigoraki A, Girolomoni G (2008) Sensitizing potential of triclosan and triclosan-based skin care products in patients with chronic eczema. Dermatol Ther 2:S35-S38

Schiffer C, Muller A, Egeberg CL, Alvarez L, Brenker CA, Frederiksen H, Waschle B, Kaupp UB, Balbach M, Wachten D, Skakkebaek NE, Almstrup K, Strunker T (2014) Direct action of endocrine disrupting chemicals on human sperm. EMBO Rep 15(7):758-765

Schweizer HP (2001) Triclosan: a widely used biocide and its link to antibiotics. FEMS Microbiol Lett 202:1-7

Serrano M, Robatzek S, Torres M, Kombrink E, Somssich IE, Robinson E, Schulze-Lefert P (2007) Chemical interference of pathogen-associated molecular pattern-triggered immune responses in Arabidopsis reveals a potential role for fatty-acid synthase type II complex-derived lipid signals. J Biol Chem 282(9):6803-6811

Shen JY, Chang MS, Yang SH, Wu GJ (2012) Simultaneous and rapid determination of triclosan, triclocarban and their four related transformation products in water samples using SPME-HPLC-DAD. J Liq Chromatogr Relat Technol 35(16):2280-2293

Shim J, Weatherly LM, Luc RH, Dorman MT, Neilson A, Ng R, Kim CH, Millard PJ, Gosse JA (2016) Triclosan is a mitochondrial uncoupler in live zebrafish. J Appl Toxicol. doi:10.1002/jat.3311. Accessed 1 June 2016

Singer H, Muller S, Tixier C, Pillonel L (2002) Triclosan: occurrence and fate of a widely used biocide in the aquatic environment: field measurements in wastewater treatment plants, surface waters, and lake sediments. Environ Sci Technol 36(23):4998-5004

Snyder SA, Wert EC, Lei H, Westerhoff P, Yoon Y (2007) Removal of EDCs and pharmaceuticals in drinking and reuse treatment processes. Awwa Research Foundation, Denver

Snyder SA, Vanderford BJ, Drewes J, Dickenson E, Snyder EM, Bruce GM, Pleus RC (2008) State of knowledge of endocrine disruptors and pharmaceuticals in drinking water. Awwa Research Foundation, Denver

Soares S, Mateus N, Freitas V (2007) Interaction of different polyphenols with bovine serum albumin (BSA) and human salivary R-amylase (HSA) by fluorescence quenching. J Agric Food Chem 55:6726-6735

Solomon GM, Schettler T (2000) Environment and health: endocrine disruption and potential human health implications. CMAJ 163(11):1471-1476

Son HS, Ko G, Zoh KD (2009) Kinetics and mechanism of photolysis and $\mathrm{TiO}_{2}$ photocatalysis of triclosan. J Hazard Mater 166:954-960

Sorensen JPR, Lapworth DJ, Nkhuwa DCW, Stuart ME, Gooddy DC, Bell RA, Chirwa M, Kabika J, Liemisa M, Chibesa M, Pedley S (2015) Emerging contaminants in urban groundwater sources in Africa. Water Res 72:51-63

Spanier AJ, Fausnight T, Camacho TF, Braun JM (2014) The associations of triclosan and paraben exposure with allergen sensitization and wheeze in children. Allergy Asthma Proc 35(6):475-481

Sporik R, Kemp AS (1997) Topical triclosan treatment of atopic dermatitis. J Allergy Clin Immunol 99:861

Stasinakis AS, Petalas AV, Mamais D, Thomaidis NS, Gatidou G, Lekkas TD (2007) Investigation of triclosan fate and toxicity in continuous-flow activated sludge systems. Chemosphere 68:375-381

Stoker TE, Gibson EK, Zorrilla LM (2010) Triclosan exposure modulates estrogen-dependent responses in the female Wistar rat. Toxicol Sci 117(1):45-53

Suarez S, Dodd MC, Omil F, von Gunten U (2007) Kinetics of triclosan oxidation by aqueous ozone and consequent loss of antibacterial activity: relevance to municipal wastewater ozonation. Water Res 41:2481-2490
Suller MTE, Russell AD (1999) Antibiotic and biocide resistance in methicillinresistant Staphylococcus aureus and vancomycin-resistant enterococcus. J Hosp Infect 43:281-291

Svenningsen $\mathrm{H}$, Henriksen T, Priemé A, Johnsen AR (2011) Triclosan affects the microbial community in simulated sewage-drain-field soil and slows down xenobiotic degradation. Environ Pollut 159:1599-1605

Svenson A, Allard AS, Ek M (2003) Removal of estrogenicity in Swedish municipal sewage treatment plants. Water Res 37:4433-4443

Tamura I, Kanbara Y, Saito M, Horimoto K, Satoh M, Yamamoto H, Oyama Y (2012) Triclosan, an antibacterial agent, increases intracellular $\mathrm{Zn}^{2+}$ concentration in rat thymocytes: its relation to oxidative stress. Chemosphere 86:70-75

Tan WP, Suresh S, Tey HL, Chiam LY, Goon AT (2010) A randomized double-blind controlled trial to compare a triclosan-containing emollient with vehicle for the treatment of atopic dermatitis. Clin Exp Dermatol 35:109-112

Taştana BE, Dönmeza G (2015) Biodegradation of pesticide triclosan by A. versicolor in simulated wastewater and semi-synthetic media. Pestic Biochem Physiol 118:33-37

Tatarazako N, Ishibashi H, Teshima K, Kishi K, Arizono K (2004) Effects of triclosan on various organisms. Environ Sci 11(2):133-140

TIME (2014) Minnesota bans antibacterial triclosan. TIME Newspaper U.S. May 19,2014

Tixier C, Singer HP, Canonica S, Muller SR (2002) Phototransformation of triclosan in surface waters: a relevant elimination process for this widely used biocide-laboratory studies, field measurements, and modelling. Environ Sci Technol 36:3482-3489

Tohidi F, Cai Z (2016) Fate and mass balance of triclosan and its degradation products: comparison of three different types of wastewater treatments and aerobic/anaerobic sludge digestion. J Hazard Mater. doi:10.1016/j. jhazmat.2016.04.034. Accessed 16 May 2016

Tuffnell DJ, Croton RS, Hemingway DM, Hartley MN, Wake PN, Garvey RJ (1987) Methicillin resistant Staphylococcus aureus; the role of antisepsis in the control of an outbreak. J Hosp Infect 10(3):255-259

US FDA (2008) Triclosan; supporting information for toxicological evaluation by the national toxicology program, July 2008. U S Food and Drug Administration. Department of Health and Human Services

US EPA (2008c) US Environmental Protection Agency. Cancer assessment document: evaluation of the carcinogenic potential of triclosan. Final, January 4, 2008. Washington (DC): US Environmental Protection Agency, Office of Prevention, Pesticides and Toxic Substances. www.regulations. gov/\#!searchResults; $;$ pp $=10 ; p o=10 ; s=E P A-H Q-O P P-2007-0513$

US FDA (2010) Chapter 1—food and drug administration, Department of Health and Human Services, sub-chapter E-animal drugs, feeds, and related products, part 556-tolerances for residues of new animal drugs in food-Sub-part B - specific tolerance for residues of new animal drugs—section 556.286—Flunixin. In: Administration U.S.F.a.D. (ed) United States Food and Drug Administration, Washington, DC, USA (21 CF 556286)

US CDC (2014) Fourth national report on human exposure to environmental chemicals updated tables, July 2014. US Department of Health and Human Services Centres for Disease Control. http://www.cdc.gov/exposurereport/pdf/FourthReport_UpdatedTables_Jul2014.pdf. Accessed 22 May 2016

US EPA US Environmental Protection Agency (2008e) Revised environmental fate science chapter for the triclosan reregistration eligibility decision (RED) document. Reregistration Case No.: 2340. Washington (DC): US Environmental Protection Agency, Office of Prevention, Pesticides and Toxic Substances, p 42

Veldhoen N, Skirrow RC, Osachoff H, Wigmore H, Clapson DJ, Gunderson MP, Van Aggelen G, Helbing CC (2006) The bactericidal agent triclosan modulates thyroid hormone-associated gene expression and disrupts postembryonic anuran development. Aquat Toxicol 80:217-227

Vélez MP, Arbuckle TE, Fraser WD (2015) Female exposure to phenols and phthalates and time to pregnancy: the Maternal-Infant Research on Environmental Chemicals (MIREC) Study. Fertil Steril 103(4):1011-1020

Villalain J, Mateo CR, Aranda FJ, Shapiro S, Micol V (2001) Membranotropic effects of the antibacterial agent triclosan. Arch Biochem Biophys 390(1):128-136

Wallet MA, Calderon NL, Alonso TR, Choe CS, Catalfamo DL, Lalane CJ, Neiva KG, Panagakos F, Wallet SM (2013) Triclosan alters antimicrobial and inflammatory responses of epithelial cells. Oral Dis 19:296-302 
Wang LQ, Falany CN, James MO (2004) Triclosan as a substrate and inhibitor of 3'-phosphoadenosine 5'-phosphosulfate-sulfotransferase and UDPglucuronosyl transferase in human liver fractions. Drug Metab Dispos 32(10):1162-1169

Wang L, Asimakopoulos AG, Kannan K (2015) Accumulation of 19 environmental phenolic and xenobiotic heterocyclic aromatic compounds in human adipose tissue. Environ Int 78:45-50

Waria M, O'Connor GA, Toor GS (2011) Biodegradation of triclosan in biosolidsamended soils. Environ Toxicol Chem 30(11):2488-2496. doi:10.1002/ etc.666

Watkinson AJ, Murby EJ, Costanzo SD (2007) Removal of antibiotics in conventional and advanced wastewater treatment: implications for environmental discharge and wastewater recycling. Water Res 41(18):4164-4176

Weatherly LM, Shim J, Hashmi HN, Kennedy RH, Hess ST, Gosse JA (2016) Antimicrobial agent triclosan is a proton ionophore uncoupler of mitochondria in living rat and human mast cells and in primary human keratinocytes. J Appl Toxicol 36:777-789. doi:10.1002/jat.3209

Weiss L, Arbuckle TE, Fisher M, Ramsay T, Mallick R, Hauser R, LeBlanc A, Walker M, Dumas P, Lang C (2015) Temporal variability and sources of triclosan exposure in pregnancy. Int J Hyg Env Health 218(6):507-513

Wijekoon KC, Hai FI, William JK, Price E, Guo W, Ngo HH, Nghiem LD (2013) The fate of pharmaceuticals, steroid hormones, phytoestrogens, UV-filters and pesticides during MBR treatment. Bioresour Technol 144:247-254

Wilson B, Chen RF, Cantwell M, Gontz A, Zhu J, Olsen CR (2009) The partitioning of triclosan between aqueous and particulate bound phases in the Hudson River Estuary. Mar Pollut Bull 59:207-212

Wingspread Consensus Statement (1991) Statement from the work session on chemically-induced alterations in sexual development: the wildlife/ human connection. http://www.ourstolenfuture.org/Consensus/wingspread1.htm. Accessed 16 Feb 2015

Winitthana T, Lawanprasert S, Chanvorachote P (2014) Triclosan potentiates epithelial-to-mesenchymal transition in anoikis-resistant human lung cancer cells. PLoS One 9(10):e110851. doi:10.1371/journal. pone.0110851

Wolff MS, Teitelbaum SL, Windham G, Pinney SM, Britton JA, Chelimo C, Godbold J, Biro F, Kushi LH, Pfeiffer CM, Calafat AM (2007) Pilot study of urinary biomarkers of phytoestrogens, phthalates, and phenols in girls. Environ Health Perspect 115:116-121

Wong CSM, Beck MH (2001) Allergic contact dermatitis from triclosan in antibacterial handwashes. Contact Dermat 45:307

Wu C, Spongberg AL, Witter JD (2009) Adsorption and degradation of triclosan and triclocarban in soils and biosolids-amended soils. J Agric Food Chem 57(11):4900-4905. doi:10.1021/jf900376c

Wu C, Spongberg AL, Witter JD, Fang M, Czajkowski KP (2010) Uptake of pharmaceutical and personal care products by soybean plants from soils applied with biosolids and irrigated with contaminated water. Environ Sci Technol 44(16):6157-6161
Wu C, Spongberg AL, Witter JD, Sridhar BBM (2012a) Transfer of wastewater associated pharmaceuticals and personal care products to crop plants from biosolids treated soil. Ecotoxicol Environ Saf 85:104-109

Wu Q, Shi H, Adams CD, Timmons T, Ma Y (2012b) Oxidative removal of selected endocrine-disruptors and pharmaceuticals in drinking water treatment systems, and identification of degradation products of triclosan. Sci Total Environ 439:18-25

Wu Y, Wu Q, Belanda FA, Gea P, Manjanathab MG, Fanga JL (2014) Differential effects of triclosan on the activation of mouse and human peroxisome proliferator-activated receptor alpha. Toxicol Lett 231(1):17-28

Wu Y, Beland FA, Chen S, Fang JL (2015) Extracellular signal-regulated kinases $1 / 2$ and Akt contribute to triclosan-stimulated proliferation of JB6 Cl 41-5a cells. Arch Toxicol 89:1297-1311

Xia K, Hundal LS, Kumar K, Armbrust K, Cox AE, Granato TC (2010) Triclocarban, triclosan, polybrominated diphenyl ethers, and 4-nonylphenol in biosolids and in soil receiving 33-year biosolids application. Environ Toxicol Chem 29:597-605

Xue J, Wu Q, Sakthivel S, Pavithran PV, Vasukutty JR, Kannan K (2015) Urinary levels of endocrine-disrupting chemicals, including bisphenols, bisphenol A diglycidyl ethers, benzophenones, parabens, and triclosan in obese and non-obese Indian children. Environ Res 137:120-128. doi:10.1016/j.envres.2014.12.007

Yang GCC, Yena CH, Wang CL (2014) Monitoring and removal of residual phthalate esters and pharmaceuticals in the drinking water of Kaohsiung City, Taiwan. J Hazard Mater 277:53-61

Yin J, Wei L, Shi Y, Zhang J, Wu Q, Shao B (2015) Chinese population exposure to triclosan and triclocarban as measured via human urine and nails. Environ Geochem Health. doi:10.1007/s10653-015-9777-x. Accessed 31 May 2016

Ying GG, Kookana RS (2007) Triclosan in effluents and biosolids from Australian wastewater treatment plants. Environ Int 33:199-205

Ying GG, Yu XY, Kookana RS (2007) Biological degradation of triclocarban and triclosan in a soil under aerobic and anaerobic conditions and comparison with environmental fate modelling. Environ Pollut 150(3):300-305

Yueh MF, Taniguchi K, Chen S, Evans RM, Hammock BD, Karin M, Tukey RH (2014) The commonly used antimicrobial additive triclosan is a liver tumor promoter. Proc Natl Acad Sci USA 111(48):17200-17205

Zafar A, Butler R, Reese D, Gaydos L, Mennonna P (1995) Use of 0.3\% triclosan (Bacti-Stat) to eradicate an outbreak of methicillin-resistant Staphylococcus aureus in a neonatal nursery. Am J Infect Control 23:200-208

Zhang H, Huang C (2003) Oxidative transformation of triclosan and chlorophene by manganese oxides. Environ Sci Technol 37:2421-2430

Ziylan A, Ince NH (2011) The occurrence and fate of anti-inflammatory and analgesic pharmaceuticals in sewage and fresh water: treatability by conventional and non-conventional processes. J Hazard Mater 187(1-3):24-36

\section{Submit your manuscript to a SpringerOpen ${ }^{\circ}$ journal and benefit from:}

- Convenient online submission

- Rigorous peer review

- Immediate publication on acceptance

- Open access: articles freely available online

- High visibility within the field

- Retaining the copyright to your article

Submit your next manuscript at springeropen.com 